Selected Meteorological Data for an Arid Climate Over Bare Soil Near Beatty, Nye County, Nevada, November 1977 through May 1980

By Robin G. Brown and William D. Nichols

U.S. GEOLOGICAL SURVEY

Open-File Report 90-195

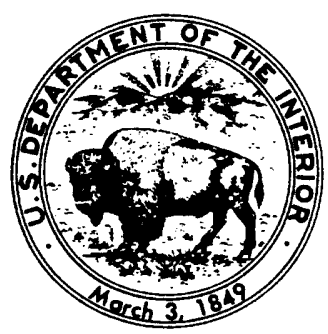

Carson City, Nevada 1990 
DEPARTMENT OF THE INTERIOR

MANUEL LUJAN, JR., Secretary

\section{U.S. GEOLOGICAL SURVEY}

Dallas L. Peck, Director

For additional information write to:

U.S. Geological Survey Room 227, Federal Building 705 North Plaza Street Carson City, NV 89701
Copies of this report may be purchased from:

U.S. Geological Survey

Books and Open-File Reports Section

Federal Center, Building 810

Box 25425

Denver, CO 80225 


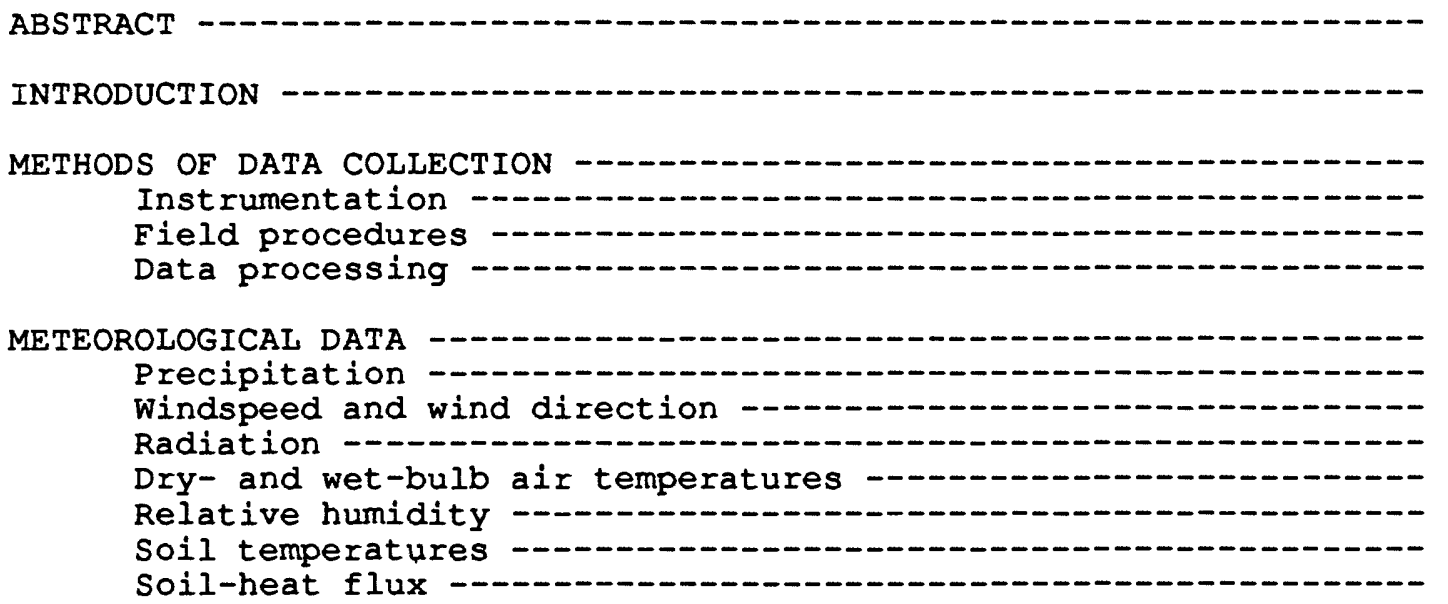

PARTIAL SOLAR ECLIPSE

SUMMARY

SUMMARY

\section{ILIUSTRATIONS}

Figure 1. Map showing location of burial site for low-level radioactive waste -

2. Sketch showing location of weather-instrument shelter adjacent to burial site for low-level radioactive waste

3. Photograph showing weather-instrument shelter -.....-.--

4, 5. Graphs showing hourly averaged incident and reflected solar radiation, and net radiation for periods:

4. July 19-24, 1979 -

5. March 1-6, 1980 _...........

6 , 7. Graphs showing hourly averaged dry- and wet-bulb air temperatures at a height of 50 centimeters above soil surface for periods:

6. July 19-24, 1979

7 March 1-6, 1980

8, 9. Graphs showing hourly averaged dry- and wet-bulb air temperatures at a height of 100 centimeters above soil surface for periods:

8. July 19-24, 1979

9. March 1-6, $1980 \ldots 13$

10, 11. Graphs showing hourly averaged soil temperatures at depths of $5,10,30$, and 100 centimeters below the soil surface for periods:

10. July 19-24, 1979 - 16

11. March 1-6, 1980

12, 13. Graphs showing hourly averaged soil-heat flux at depths of 1 and 5 centimeters below the soil surface for periods:

12. July 19-24, 1979

13. March 1-6, $1980 \ldots 19$ 
Figures 14, 15. Graphs showing meteorological data for October 12, 1977:

14. Incident solar radiation and net radiation -.-

15. Comparison of temperature from flate-plate net radiometer to dry- and wet-bulb air temperatures at height of 100 centimeters above soil surface -......

TABLE

Table 1. Selected meteorological data, November 1977 through

May 1980

\section{CONVERSION FACTORS AND ABBREVIATIONS}

International system (metric) units of measure used in this report may be converted to "Inch-pound" units by using the following factors:

Multiply

Centimeters $(\mathrm{cm})$

Kilometers $(\mathrm{km})$

Kilopascals (kPa)

Kilopascals ( $\mathrm{kPa})$

Meters (m)

Meters per second $(\mathrm{m} / \mathrm{s})$

Pascals ( $\mathrm{Pa})$
By

$$
0.3937
$$

0.6214

0.1450

100.00

3.281

3.281

100.00
To obtain

Inches (in.)

Miles (mi)

Pound per square inch $\left(\mathrm{lb} / \mathrm{in}^{2}\right)$

Bars (b)

Feet ( $f t$ )

Feet per second ( $\mathrm{ft} / \mathrm{s}$ )

Millibars (mb)

For temperature, degrees Celsius $\left({ }^{\circ} \mathrm{C}\right)$ can be converted to degrees Fahrenheit $\left({ }^{\circ} \mathrm{F}\right)$ by using the formula ${ }^{\circ} \mathrm{F}=\left[(1.8)\left({ }^{\circ} \mathrm{C}\right)\right]+32$.

SEA LEVEL

In this report, "sea level" refers to the National Geodetic Vertical Datum of 1929 (NGVD of 1929), which is derived from a general adjustment of the first-order leveling networks of both the United States and Canada (formerly called "Sea-Level Datum of 1929"). 


\title{
Selected Meteorological Data for an Arid Climate Over Bare Soil Near Beatty, Nye County, Nevada, November 1977 through May 1980
}

By Robin G. Brown and William D. Nichols

\begin{abstract}
Meteorological data were collected over bare soil at a site for low-level radioactive-waste burial near Beatty, Nevada, from November 1977 to May 1980. The data include precipitation, windspeed, wind direction, incident solar radiation, reflected solar radiation, net radiation, dry- and wet-bulb air temperatures at three heights, soil temperature at five depths, and soil-heat flux at three depths. Mean relative humidity was computed for each day of the collection period for which data are available.

A discussion is presented of the study site and the instrumentation and procedures used for collecting and processing the data. Selected data from November 1977 to May 1980 are presented in tabular form. Diurnal fluctuations of selected meteorological variables for representative summer and winter periods are graphically presented. The effects on selected variables of a partial solar eclipse are also discussed.
\end{abstract}




\section{INTRODUCTION}

Meteorological data were collected at a burial site for low-level radioactive waste near Beatty, Nev., in support of a study to estimate the potential for downward movement of radionuclides into the unsaturated sediments beneath waste-burial trenches at the site (Nichols, 1987). The data were collected to calibrate a long-term water-balance model. This report presents the meteorological data collected from November 1977 to May 1980.

The waste-burial site is in the Amargosa Desert $17.4 \mathrm{~km}$ southsoutheast of Beatty in Nye County (figure 1). The site is in the north half of section 35, T. 15 S., R. 47 E., Mount Diablo base line and meridian.

The geographic setting of the site has been described by Nichols (1987). The waste-burial facility is at an altitude of $847 \mathrm{~m}$ above sea level.

The site is in one of the most arid sections of the United States and has an average annual precipitation between $11.4 \mathrm{~cm}$ at Beatty and $7.4 \mathrm{~cm}$ at Lathrop wells $30 \mathrm{~km}$ to the southeast. The mean annual temperature at Beatty is $25^{\circ} \mathrm{C}$ and at Lathrop Wells, $27{ }^{\circ} \mathrm{C}$. The average of maximum daily temperatures during July (the hottest month) is $37{ }^{\circ} \mathrm{C}$ at Beatty and $39{ }^{\circ} \mathrm{C}$ at Lathrop Wells. The average of minimum daily temperatures during December, January, and February is near $0{ }^{\circ} \mathrm{C}$ at both stations.

The meteorological data collected include precipitation, windspeed, wind direction, incident solar radiation, reflected solar radiation, net radiation, dry- and wet-bulb air temperatures at three heights, soil temperatures at five depths, and soil-heat flux at three depths. Mean relative humidity was computed for each day of the collection period for which data are available.

An instrument shelter, which housed the recording system, was north of the waste-burial site (figure 2). The cover over the waste-burial trenches is cleared of vegetation, so to measure conditions as they exist over the buried wastes, the meterological instrumentation was situated in an area of bare soil. 

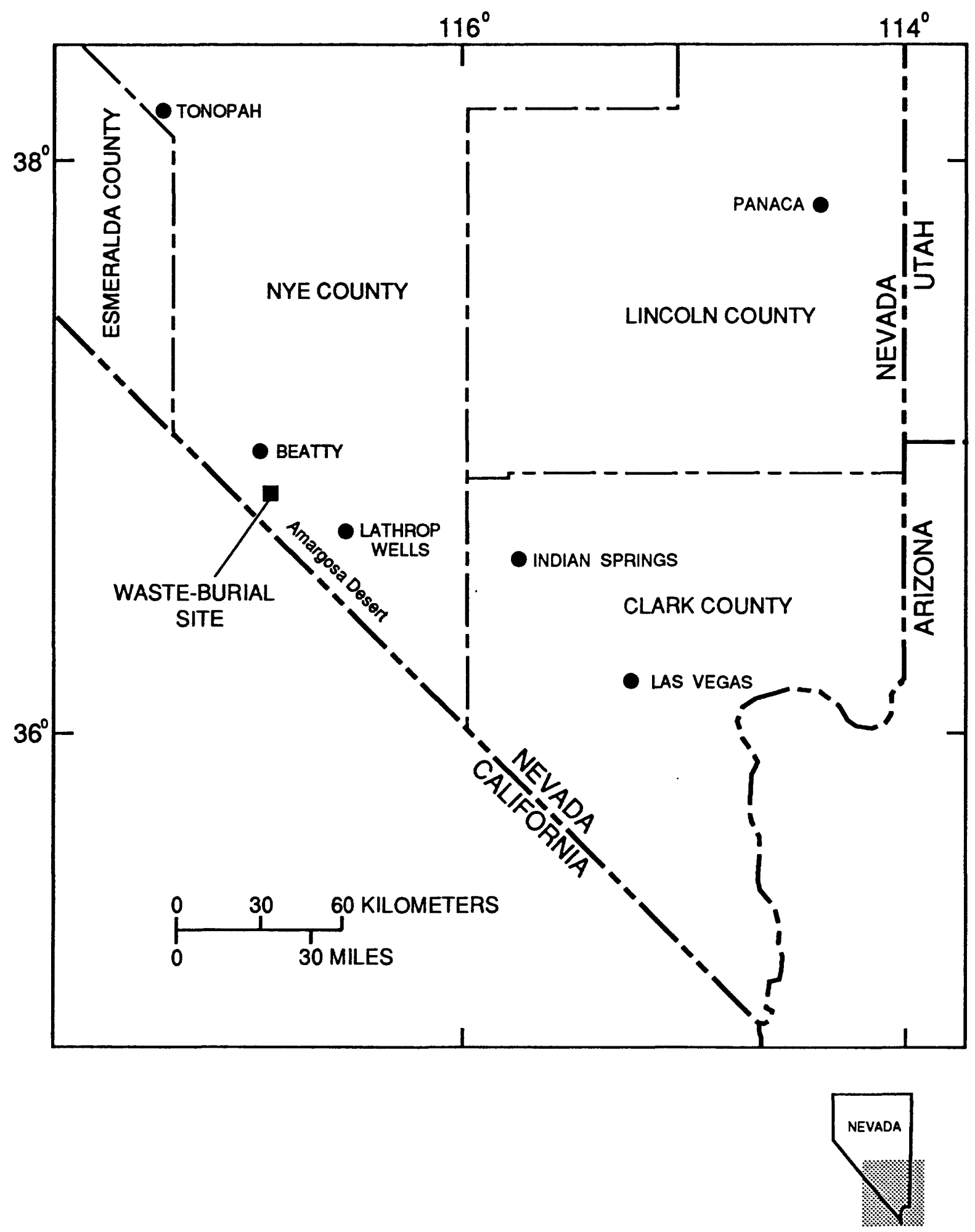

FIGURE 1.--Location of burial site for low-level radioactive waste. 


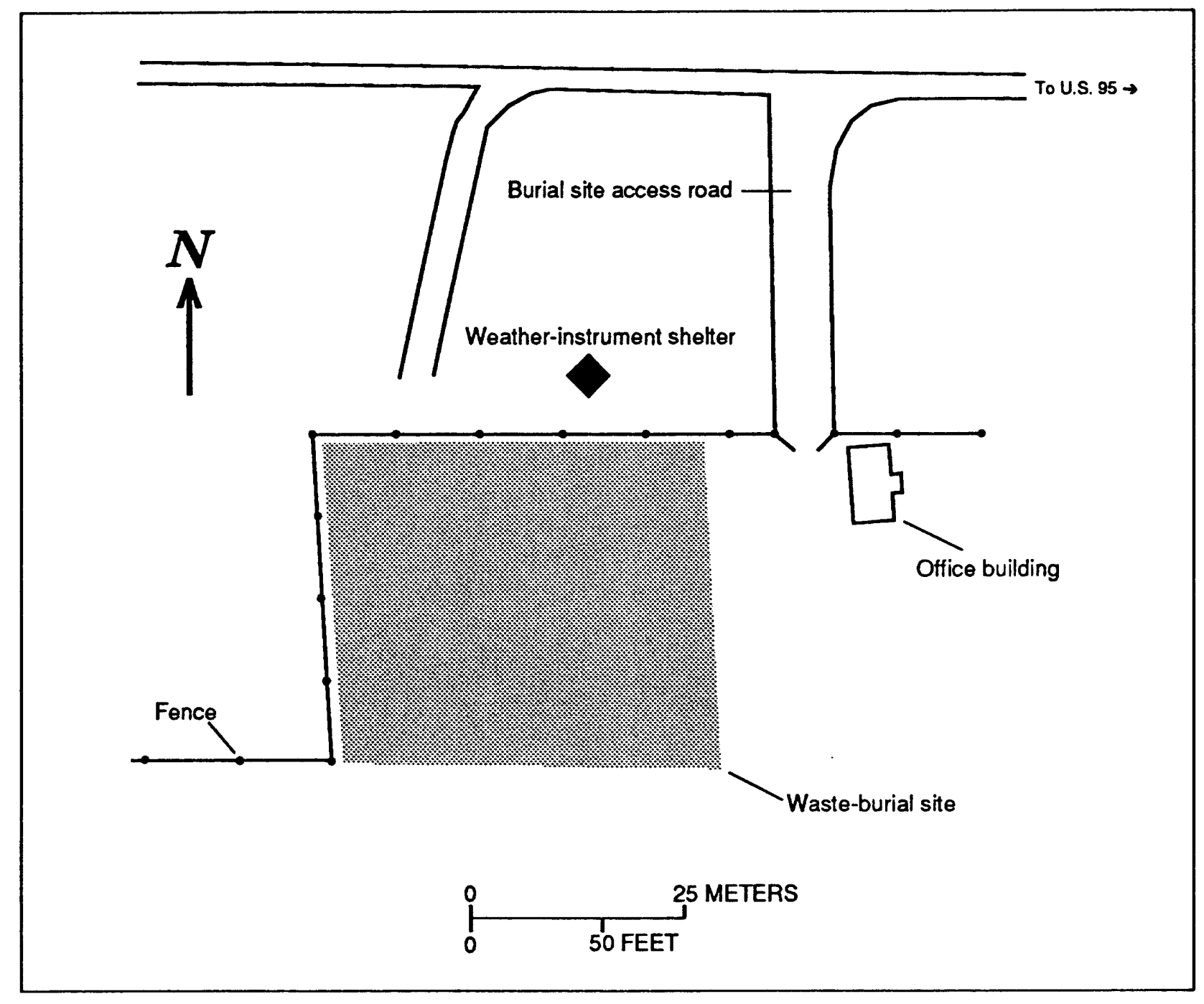

FIGURE 2.--Sketch showing location of weather-instrument shelter adjacent to burial site for low-level radioactive waste. (Location of waste-burial site is shown in figure 1.) 


\section{Inst rumentation}

The meteorological station recorded precipitation; incident solar radiation; reflected solar radiation; net radiation; dry- and wet-bulb air temperatures at 50, 100, and $200 \mathrm{~cm}$ above the soil surface; windspeed and wind direction at $100 \mathrm{~cm}$ above the soil surface; soil temperatures at depths of $1,5,10,30$, and $100 \mathrm{~cm}$ below the soil surface; and soil-heat flux at depths of 1,5 , and $10 \mathrm{~cm}$ below the soil surface. Not all the above variables were measured throughout the collection period. In addition, some meteorological data were collected prior to November 1977 as instruments were being mounted at the weather station and tested. Instrument failure occasionally caused loss of data.

From November 1, 1977, to June 9, 1978, precipitation, incident solar radiation, net radiation, dry- and wet-bulb air temperatures at 50 and $100 \mathrm{~cm}$ above the soil surface, and soil temperatures at depths of 5,10 , and $30 \mathrm{~cm}$ below the soil surface were measured. All the data except precipitation were recorded on analog charts. Data were recorded every 12 minutes. Precipitation was recorded continuously on a 7-dayevent recorder. On June 9, 1978, soil-heat flux measurements at depths of 1 and $5 \mathrm{~cm}$ were added to the data collected. The analog recording equipment was replaced with digital recording equipment on March 15, 1979. Also, at that time, soil temperature at a depth of $100 \mathrm{~cm}$ was added to the data collected. Beginning July 18, 1979, measurements of windspeed and direction at $100 \mathrm{~cm}$ above the soil surface and reflected solar radiation were added. On october 26,1979 , measurements of dryand wet-bulb air temperatures at $200 \mathrm{~cm}$ above the soil surface, soil temperature at a depth of $1 \mathrm{~cm}$, and soil-heat flux at a depth of $10 \mathrm{~cm}$ were added, completing the list of measurements collected at the meterological station.

The digital recording system, installed on March 15, 1979, consisted of a digital data logger coupled with a magnetic-tape recorder. At 10-minute intervals, all the variables except precipitation were recorded on magnetic tape. At approximately 1-hour intervals, the same information was printed on paper tape by the data logger. The paper tape allowed field monitoring of the digital recording system and served as a backup record on those occasions when the magnetic-tape system failed. The recording systems were housed in an insulated plywood shelter (figure 3 ).

Precipitation was measured with a tipping-bucket rain gage. A 7day-event recorder designed to record precipitation on an analog chart was used in conjunction with the tipping-bucket rain gage. A standard $20.32 \mathrm{~cm}(8-i n c h)$ bucket gage was used as a standard for comparison to the tipping-bucket gage.

A propeller-type anemometer was used to record windspeed. The anemometer was installed $100 \mathrm{~cm}$ above ground surface and at a sufficient distance from the shelter to receive full wind exposure. Wind direction was measured by the movement of the wipe arm on a potentiometer housed in the main body of the anemometer.

Both incident and reflected solar radiation (short-wave radiation) were measured with precision spectral pyranometers. These instruments are sensitive to radiation with a wave length between 0.3 and 3 micrometers. Incident solar radiation was measured by a pyranometer mounted on the roof of the instrument shelter; reflected solar radiation was measured using an inverted pyranometer facing the soil surface at a height of $100 \mathrm{~cm}$. Net radiation was measured with a flat-plate radiometer sensitive to radiation of all wave lengths. The net radiometer was $100 \mathrm{~cm}$ above the bare soil. 


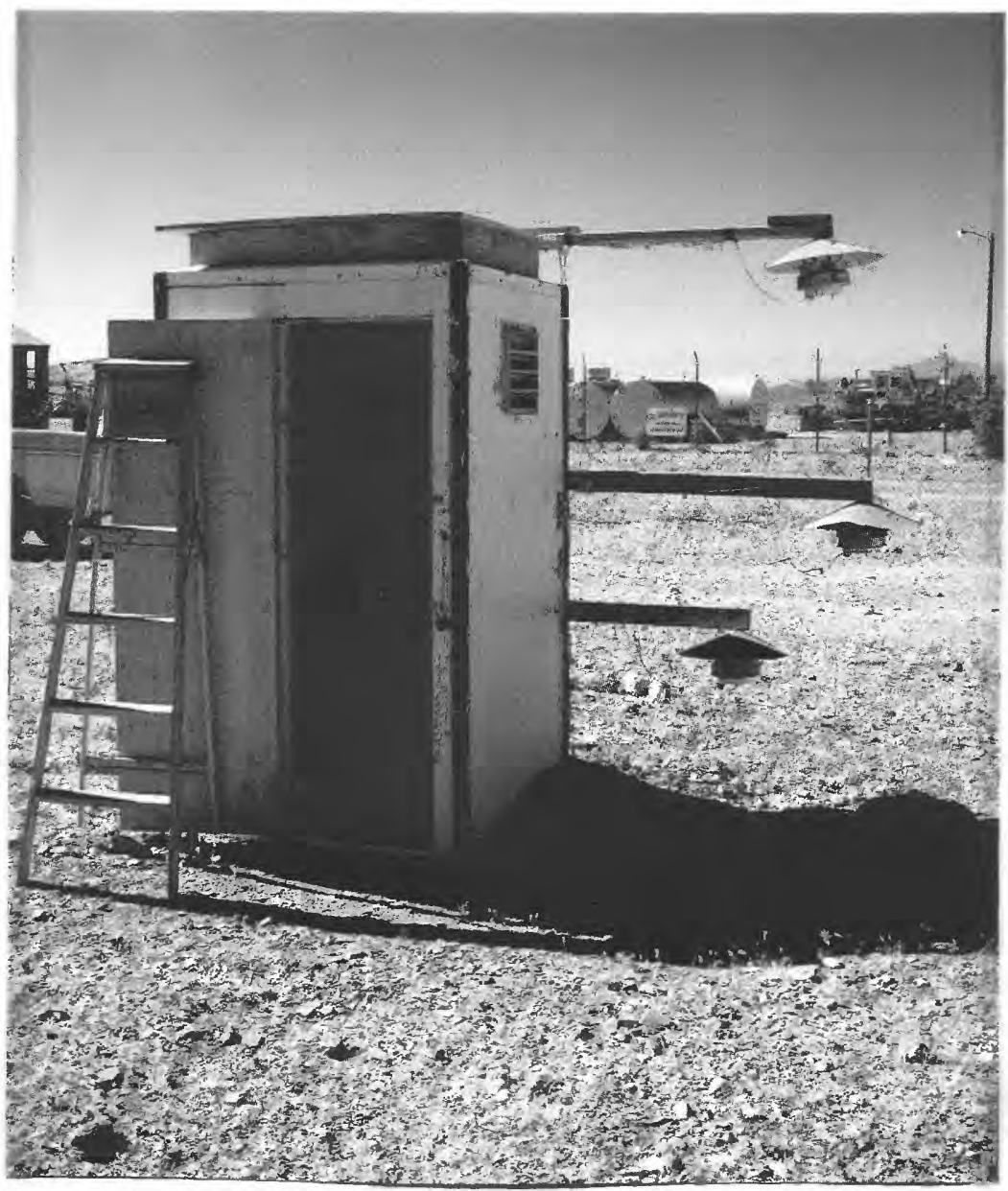

FIGURE 3.--Weather-instrument shelter. Instruments attached to beams extending from shelter are psychrometers used in measuring air temperature and wet-bulb temperature at 50, 100, and 200 centimeters above soil surface. Photograph taken during spring 1980. 
Measurements of dry- and wet-bulb air temperatures were made with ventilated, non-aspirated thermocouple psychrometers. The psychrometers were mounted under a support beam that extended from the instrumentation shelter. They were positioned on the beams so they would be 50, 100, and $200 \mathrm{~cm}$ above the bare soil surface.

Soil temperatures were measured south of the shelter with thermocouples buried in undisturbed bare soil at depths of $1,5,10,30$, and $100 \mathrm{~cm}$ below soil surface. Soil-heat flux was measured with soil-heat flux disks buried at depths of 1,5 , and $10 \mathrm{~cm}$ below the soil surface.

\section{Field Procedures}

The analog charts of both the continuous recorder and precipitation-event recorder were changed weekly. When the digital recording system was installed, the magnetic and paper tapes were changed as required.

All instrumentation was cleaned and checked every 2 days. The net radiometer and pyranometers were cleaned of any dust or particulate matter, wet-bulb reservoirs were cleaned and filled with distilled water, the anemometer was checked for lubrication, and rain gages emptied and cleaned.

\section{Date Processing}

Each analog chart consisted of 12 channels of data with 5 values per channel per hour, totaling 1,440 values per day. Electronic digitizing equipment was used to convert the data from analog to digital form. The digitized data were then used to compute average hourly values.

\section{METEOROLOGICAL DATA}

Hourly averaged values for all meteorologic data collected from November 1977 to May 1980 were averaged for each day. These daily averaged values are listed in table 1 at the back of this report. Daily averaged values for days with less than 22 hourly-averaged values are not included in the table. Average relative humidity and total precipitation is also included in table 1.

\section{Precipitation}

Total daily precipitation varied from 0 to $4.78 \mathrm{~cm}$ (table 1 ). The wet season, usualiy from January through April, accounts for most of the annual precipitation. The dry season extends from May through December, during which long periods with no measurable precipitation occur.

\section{Windspeed and Wind Direction}

Measurements of windspeed and wind direction began in July 1979. Windspeed ranges from less than $1 \mathrm{~m} / \mathrm{s}$ to almost $34 \mathrm{~m} / \mathrm{s}$ (table 1 ). Wind direction, in degrees azimuth measured clockwise from true north, indicates that the wind generally came from the south and west. However, the sparse amount of data for both windspeed and wind direction limits any conclusions about these two variables. 


\section{Radiation}

Daily averaged incident and reflected solar radiation and net radiation are listed in table 1 . Incident solar radiation is the amount of radiation that reaches the earth without interception. Reflected solar radiation is the amount of incident radiation reflected by the land surface. Net radiation is determined by measuring both incident and reflected radiation (both short-wave [solar] and long-wave radiation) and subtracting the reflected radiation from incident radiation.

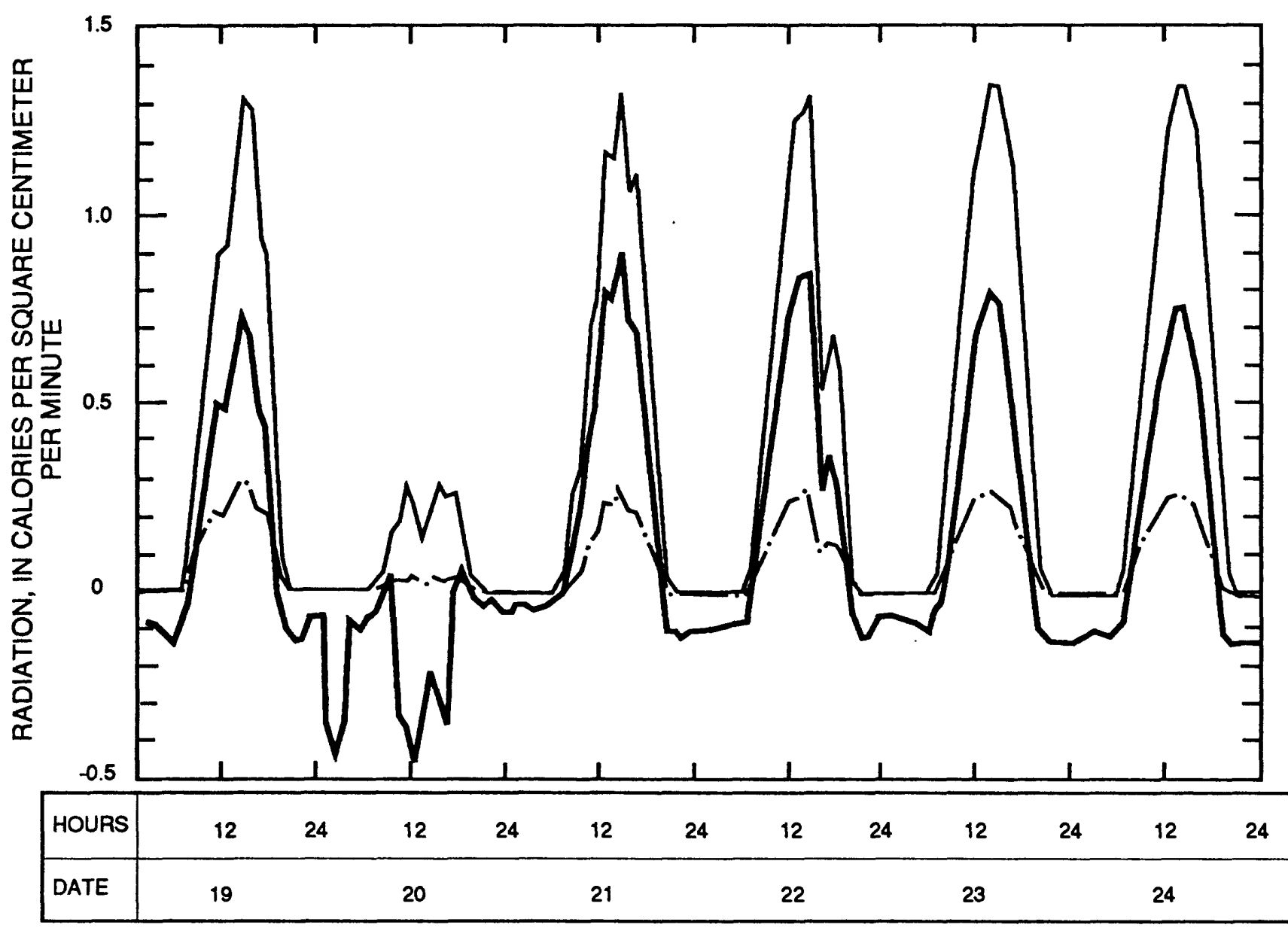

JULY 1979

EXPLANATION

FIGURE 4.--Hourly averaged incident and reflected solar radiation, and net radiation, July 19-24, 1979. 
Generally, daily averaged incident solar radiation and net radiation values were highest between May and September and lowest between December and February. Daily averaged reflected solar radiation shows a similar trend on the basis of measurements collected only for the period July 1979 through May 1980. The diurnal fluctuation in incident and reflected solar radiation, and net radiation during representative summer and winter periods are illustrated in figures 4 and 5 .

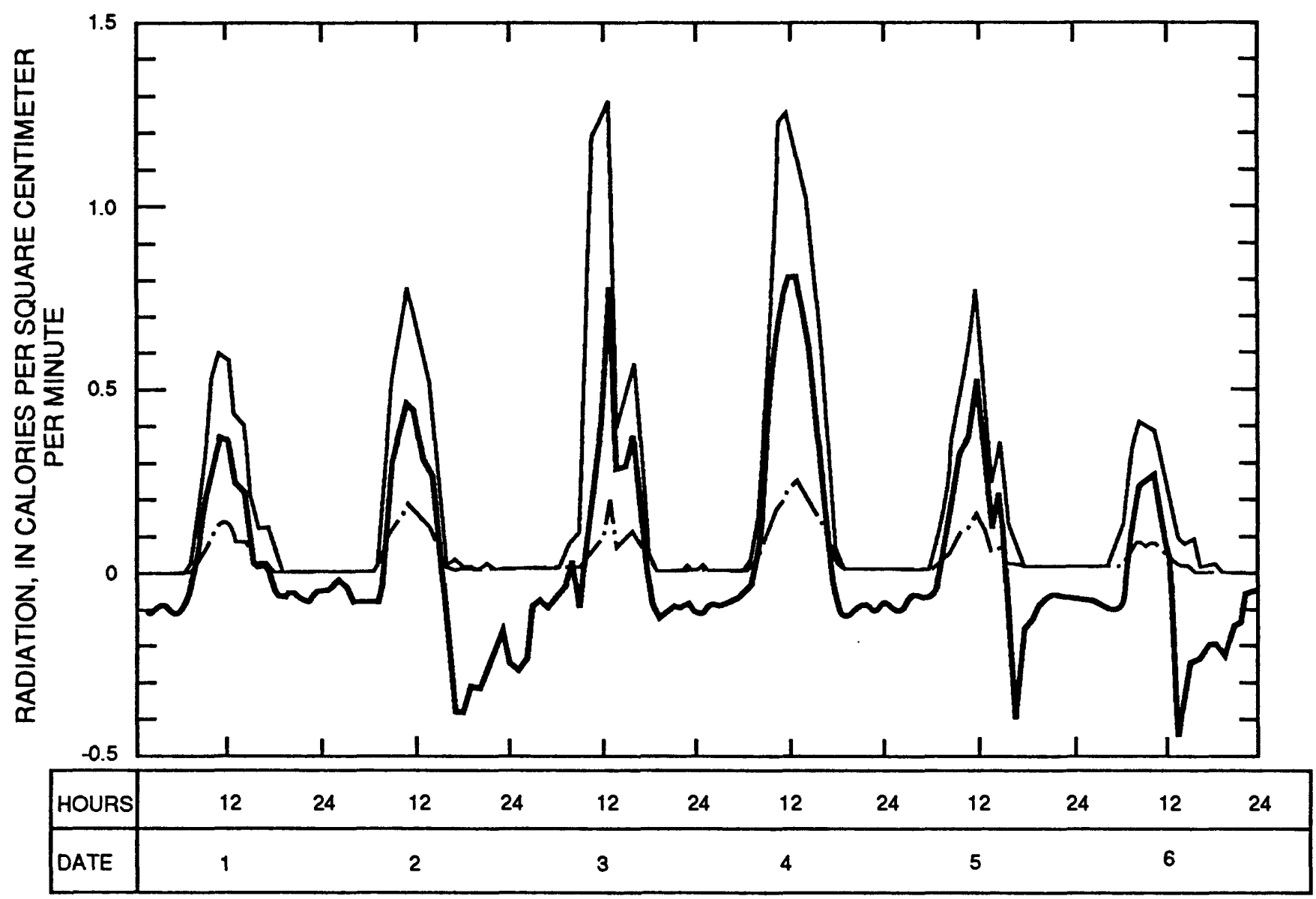

MARCH 1980

EXPLANATION

FIGURE 5.--Hourly averaged incident and reflected solar radiation, and net radiation, March 1-6, 1980. 


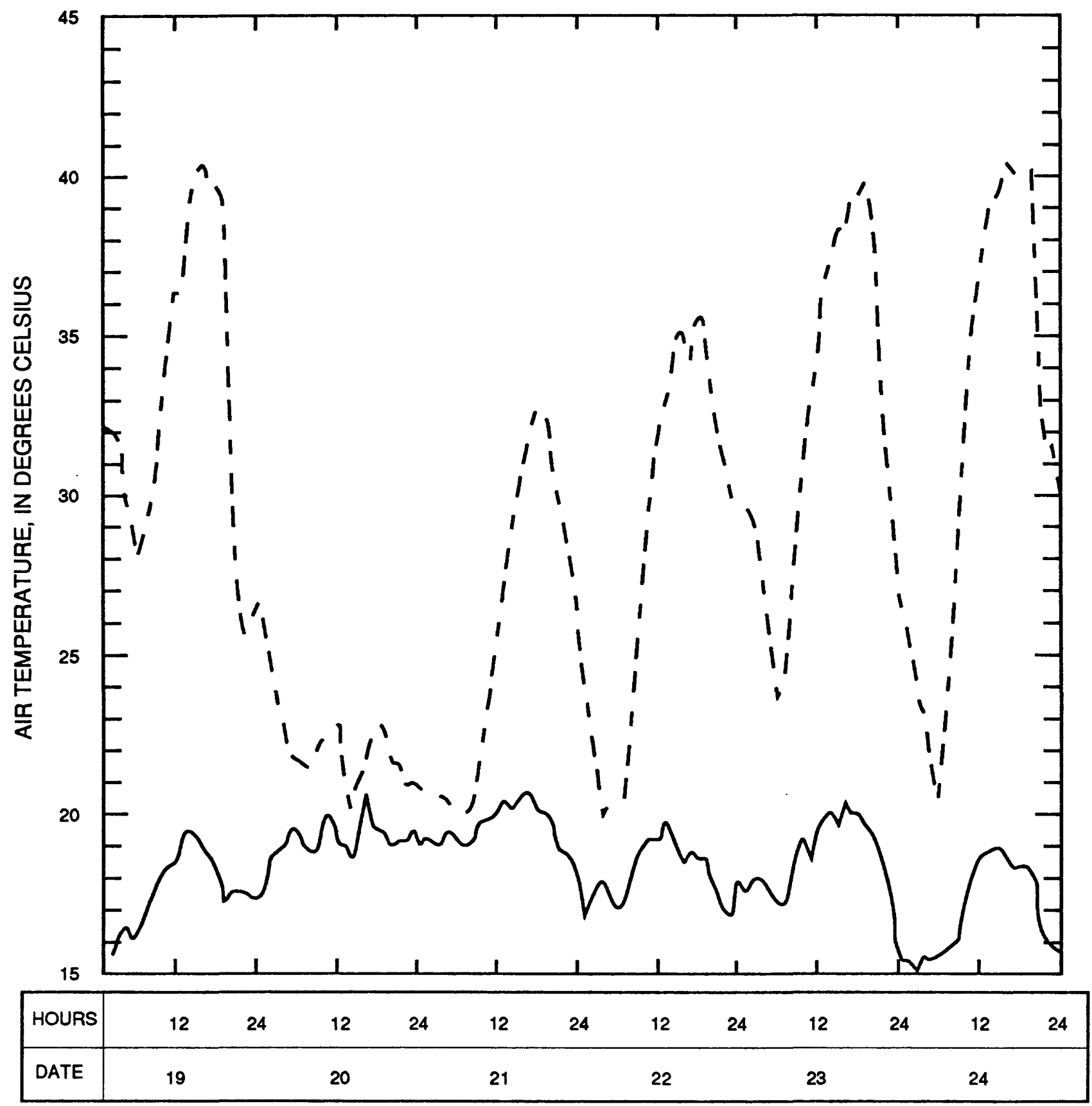

JULY 1979

EXPLANATION

- - DRY-BULB AIR TEMPERATURE

WET-BULB AIR TEMPERATURE

FIGURE 6.--Hourly averaged dry- and wet-bulb air temperatures at a height of 50 centimeters above soil surface, July 19-24, 1979. 
Daily averaged dry- and wet-bulb air temperatures at heights of $50 \mathrm{~cm}, 100 \mathrm{~cm}$, and $200 \mathrm{~cm}$ above the soil surface are given in table 1. Generally, daily averaged dry-bulb air temperatures were highest during July and August with values ranging from about 21 to $36^{\circ} \mathrm{C}$, and lowest during December, January, and February with values ranging from about 1 to $16{ }^{\circ} \mathrm{C}$. The daily averaged dry-bulb air temperatures from measurements at a height of $50 \mathrm{~cm}$ above the soil surface were typically higher than those from measurements taken at heights of 100 and $200 \mathrm{~cm}$, particularly during the months of April through september. The daily averaged wet-bulb air temperatures were consistently lower than the dry-bulb air temperatures for all heights. The diurnal variation of the dry- and wet-bulb air temperatures at 50 and $100 \mathrm{~cm}$ above soil surface during the representative 6-day periods in July and March are shown in figures 6-9.

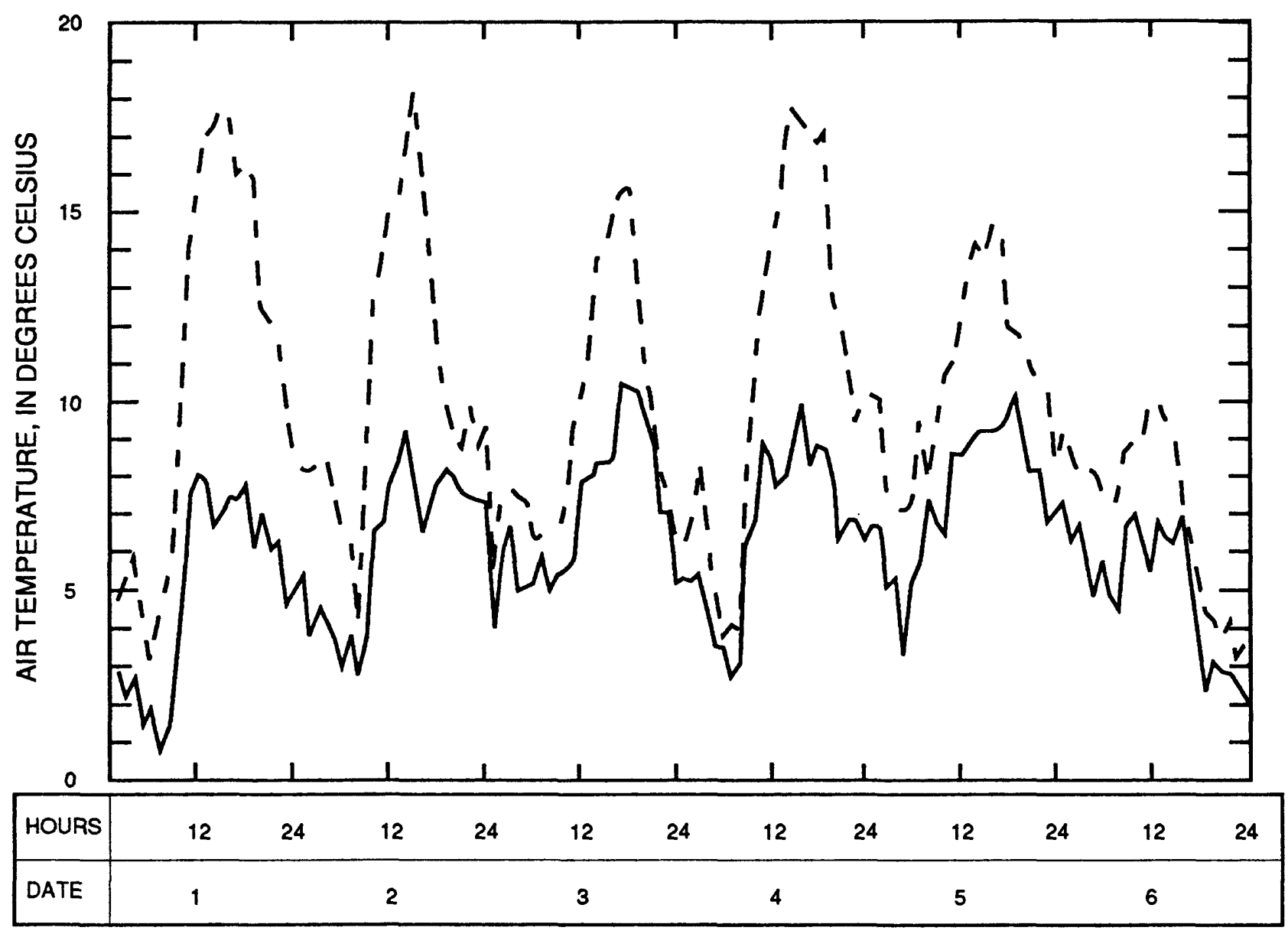

MARCH 1980

EXPLANATION

FIGURE 7.--Hourly averaged dry- and wet-bulb air temperatures at a height of 50 centimeters above soil surface, March 1-6, 1980 . 


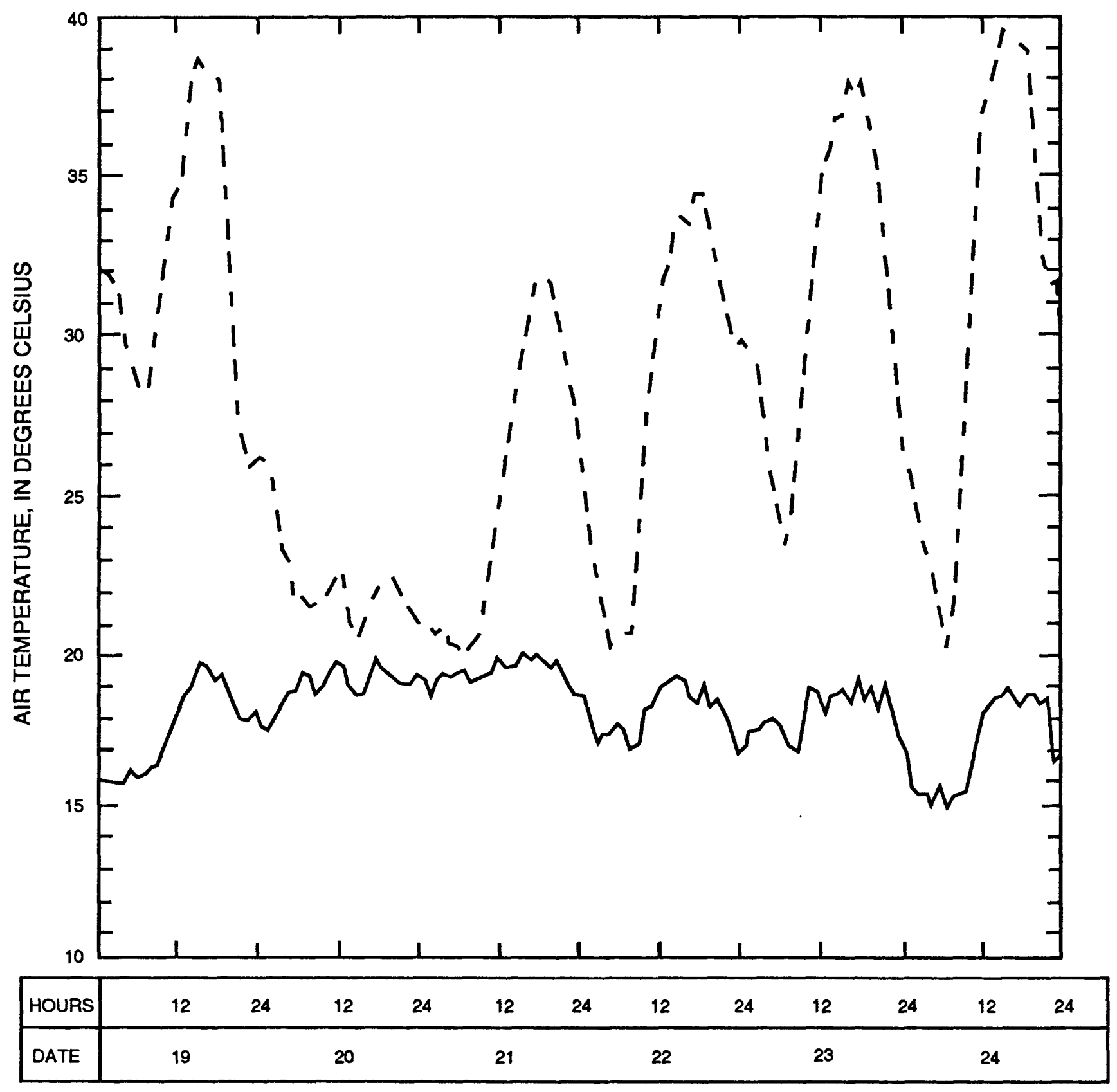

JULY 1979

\section{EXPLANATION}

\section{$-\cdots-$ DRY-BULB AIR TEMPERATURE WET-BULB AIR TEMPERATURE}

FIGURE 8.--Hourly averaged dry-and wet-bulb air temperatures at a height of 100 centimeters above soil surface, July 19-24, 1979. 


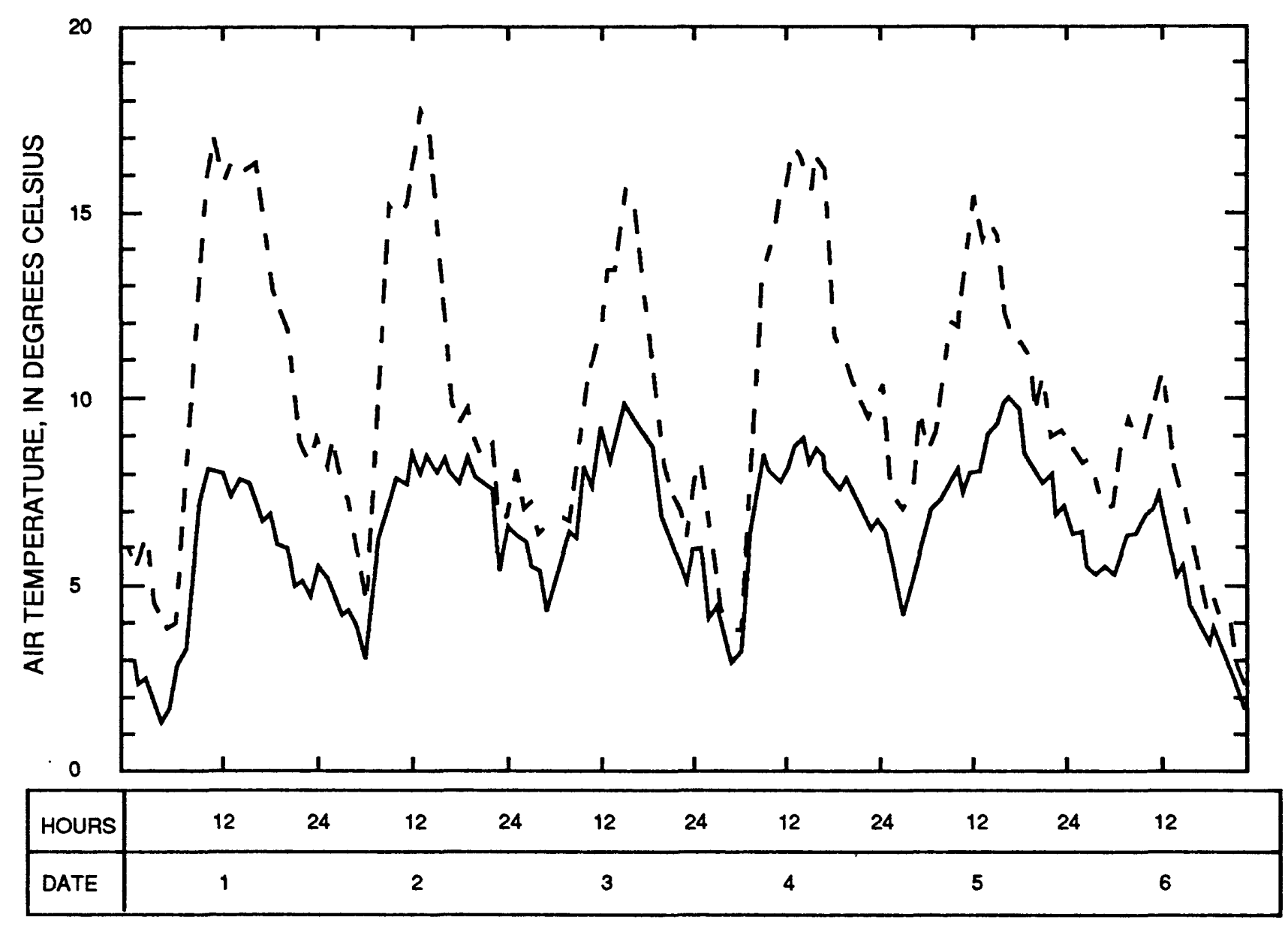

MARCH 1980

EXPLANATION

$-\cdots$ DRY-BULB AIR TEMPERATURE — WET-BULB AIR TEMPERATURE

FIGURE 9.--Hourly averaged dry- and wet-bulb air temperatures at $a$ height of 100 centimeters above soil surface, March 1-6, 1980. 


\section{Relative Humidity}

Relative humidity, or the ratio expressed as a percent of the actual amount of water vapor in the air at a specific temperature to the maximum amount of water vapor the air can hold at that temperature, was computed using the daily averaged dry- and wet-bulb air temperatures from measurements at a height of $100 \mathrm{~cm}$ above the soil surface (table 1). The following equations were used to calculate relative humidity:

$e_{s}=\exp [52.418-6788.6 /(273.16+T W)-5.0016 \ln (273.16+T W)]$,

where $e_{s}=$ saturation vapor pressure, in kilopascals, at the wet-bulb air $T W=$ wet-bulb air temperature, in degrees Celsius;

$e_{s a}=\exp [52.418-6788.6 /(273.16+T D)-5.0016 \ln (273.16+T D)]$,

where $e_{s a}=$ saturation vapor pressure, in kilopascals, at the dry-bulb air temperature, and

$T D=$ dry-bulb air temperature, in degrees Celsius; and

$$
e_{a}=e_{s}-(0.00066)(915)(T D-T W)(1+0.00115 T W),
$$

where $e_{a}=$ vapor pressure of the air, in kilopascals.

The percent of relative humidity (RH) is then computed from:

$$
\mathrm{RH}=\left(e_{a} / e_{s a}\right)(100)
$$

The smaller difference between dry- and wet-bulb air temperatures during the wet season, January through April, produced higher calculated relative humidity values compared to those calculated during the dry season, May through December. Typically, relative humidity ranges from about 10 percent during June and July to more than 90 percent for individual days during December through March. 


\section{Soil Temperatures}

Daily averaged soil temperatures at $1,5,10,30$, and $100 \mathrm{~cm}$ below soil surface are listed in table 1 . The daily averaged temperatures at all five depths are within a small range of each other. The annual fluctuation of temperature at all five depths generally follows the annual fluctuation of the air temperature. The range of soil temperatures is from near $0{ }^{\circ} \mathrm{C}$ during the winter months to $40{ }^{\circ} \mathrm{C}$ during the summer months.

Diurnal temperature fluctuations in the soil at depths of 5,10 , 30 , and $100 \mathrm{~cm}$ below the soil surface varies markedly as shown for representative 6-day periods in July and March (figures 10 and 11). Soil temperatures are based on hourly averaged values. The variability of the soil temperatures is similar in July and March, but July temperatures have a greater range. The soil temperature in July (figure 10) at a depth of $5 \mathrm{~cm}$ below the soil surface is the most extreme, with a temperature range of $22{ }^{\circ} \mathrm{C}$ during the day, compared to a $15^{\circ} \mathrm{C}$ range at a depth of $10 \mathrm{~cm}$, a $4{ }^{\circ} \mathrm{C}$ range at a depth of $30 \mathrm{~cm}$, and less than a $2{ }^{\circ} \mathrm{C}$ range at a depth of $100 \mathrm{~cm}$. The soil temperature range in March (figure 11) was $14^{\circ} \mathrm{C}$ at a depth of $5 \mathrm{~cm}, 10^{\circ} \mathrm{C}$ at a depth of $10 \mathrm{~cm}$, $3^{\circ} \mathrm{C}$ at a depth of $30 \mathrm{~cm}$, and about $1^{\circ} \mathrm{C}$ at a depth of $100 \mathrm{~cm}$. The near-surface soil temperatures, at depths of 5 and $10 \mathrm{~cm}$, have a large amplitude and closely parallel the air temperature. The temperatures farther below the surface, at 30 and $100 \mathrm{~cm}$, are not affected as much by change in air temperature and do not fluctuate as widely as near-surface temperatures.

\section{Soil-Heat Flux}

Soil-heat flux at 1,5 , and $10 \mathrm{~cm}$ below soil surface are given in table 1. The soil-heat flux, or vertical transfer of heat, is expressed in units of calories per square cm per minute. Diurnal changes in soilheat flux for representative days during July 1979 and March 1980 are shown in figures 12 and 13. Soil-heat flux in July and March is similar at depths of 1 and $5 \mathrm{~cm}$. The ranges of heat flux at a depth of $1 \mathrm{~cm}$ in July and March are larger than at a depth of $5 \mathrm{~cm}$. On July 20, 1979, soil-heat flux was depressed (figure 12) because of precipitation that occurred during that day. Precipitation also occurred on March 2, 1980, but not during the daylight hours; thus, soil-heat flux was not depressed (figure 13). 


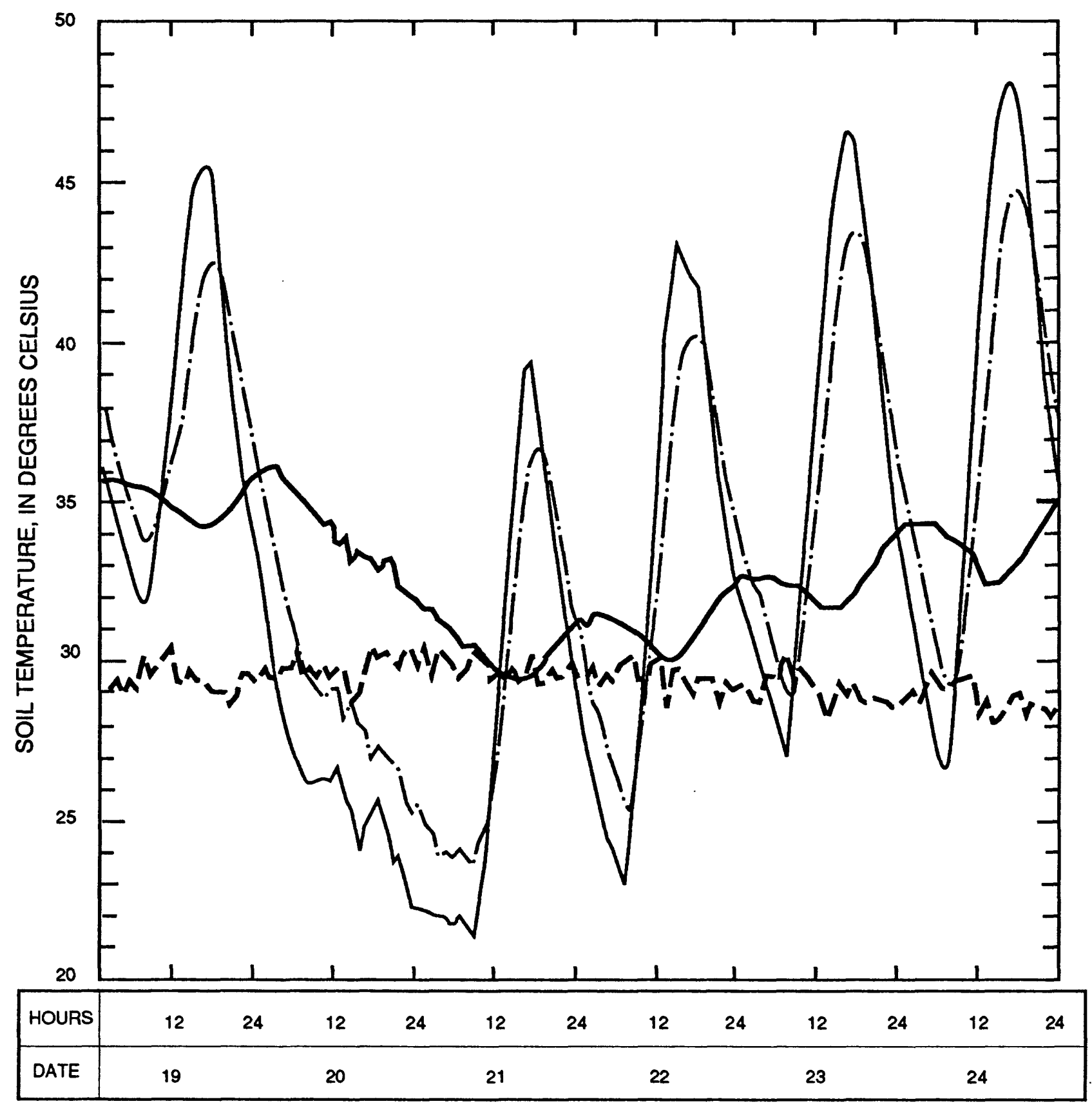

JULY 1979

EXPLANATION

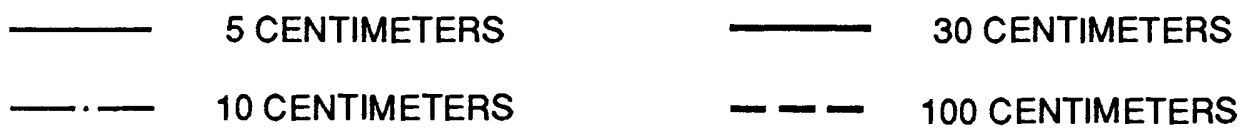

FIGURE 10.--Hourly averaged soil temperatures at depths of 5, 10, 30, and 100 centimeters below the soil surface, July 19-24, 1979. 


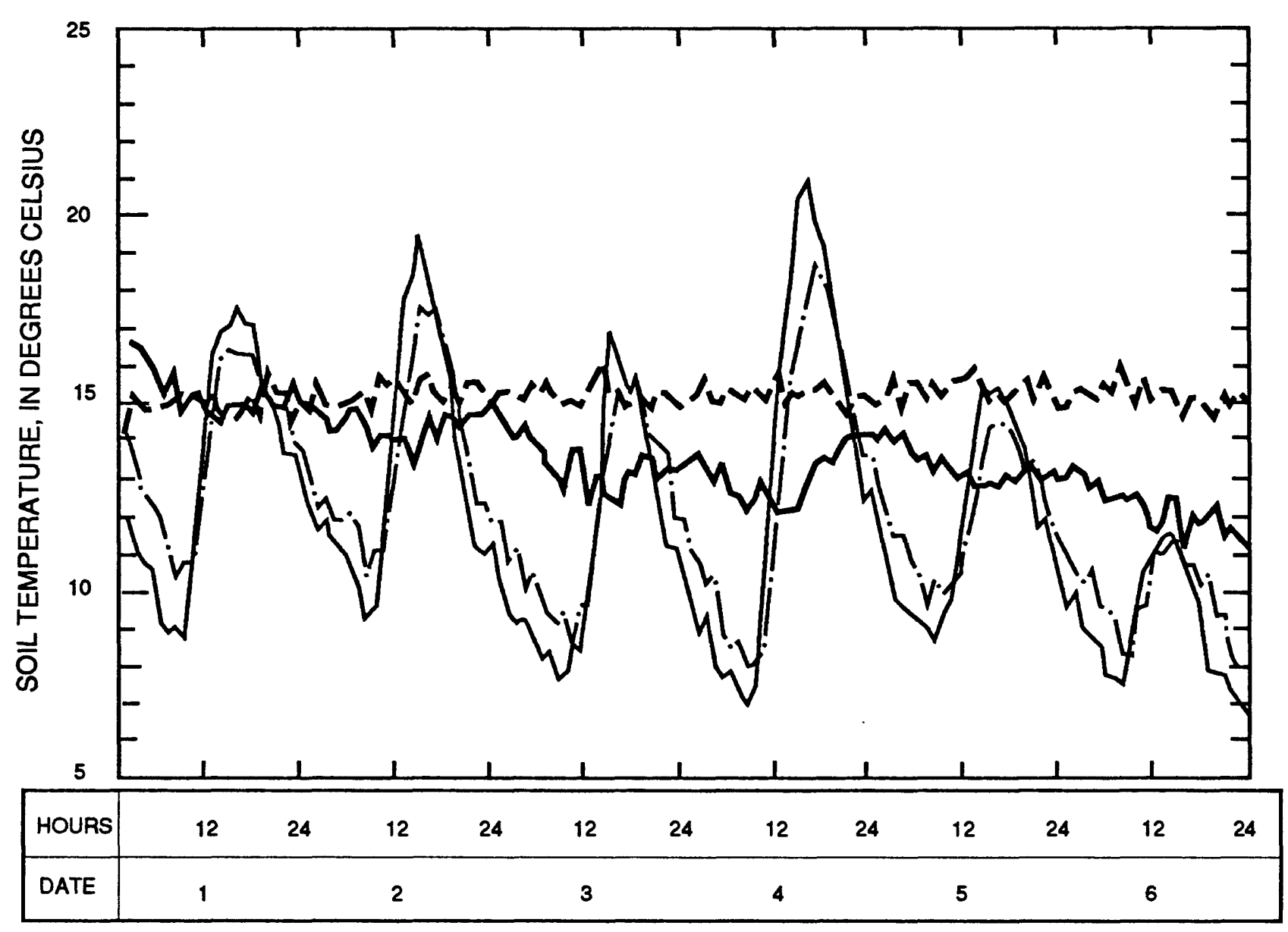

MARCH 1980

EXPLANATION

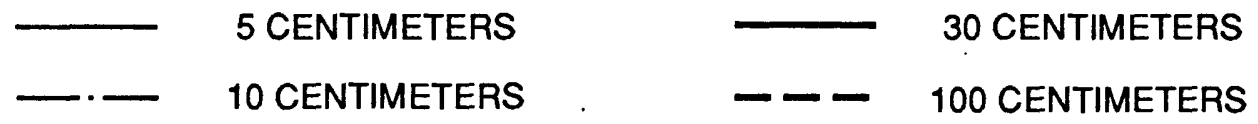

FIGURE 11.--Hourly averaged soil temperatures at depths of 5, 10, 30, and 100 centimeters below the soil surface, March 1-6, 1980. 


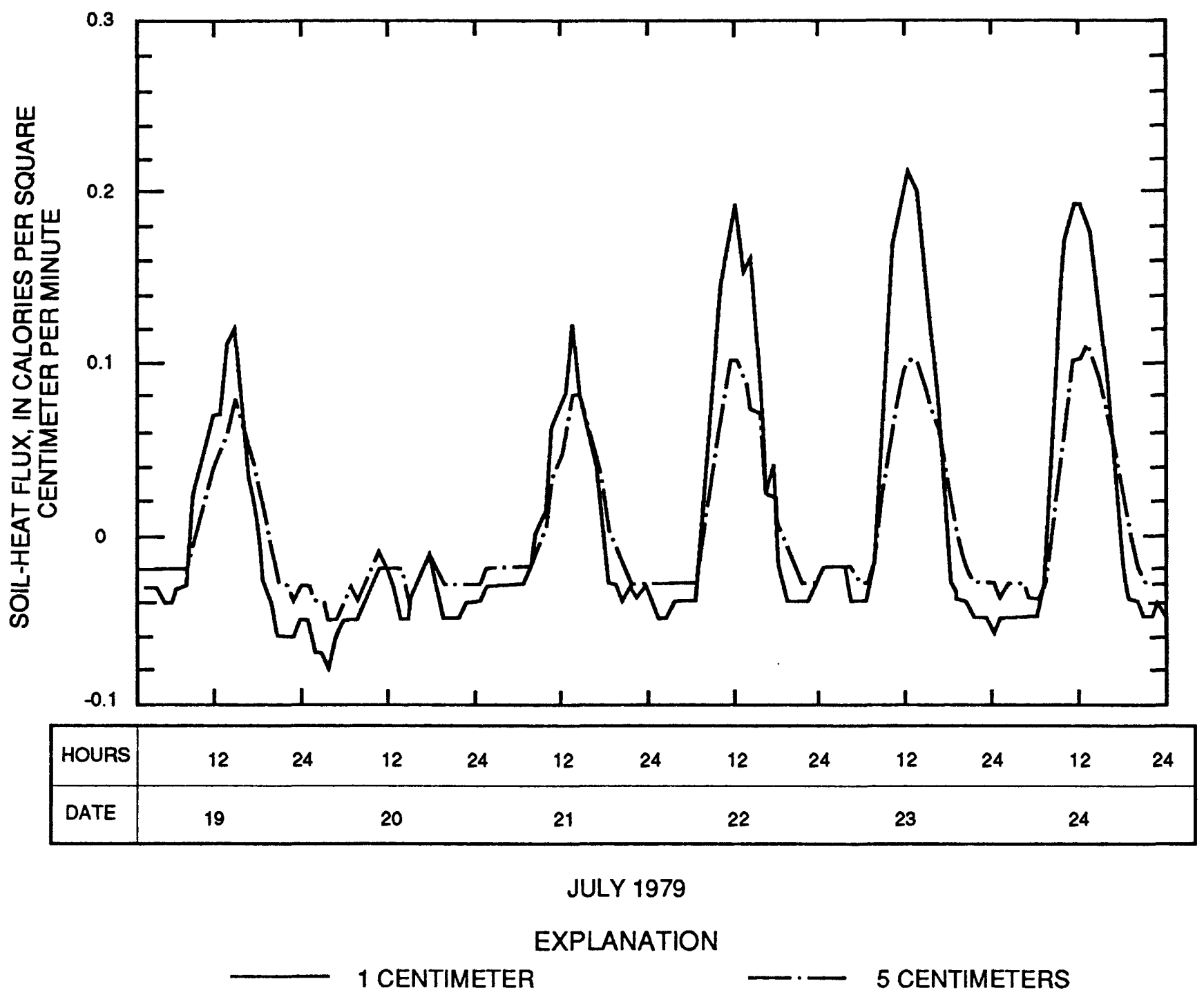

FIGURE 12.--Hourly averaged soil-heat flux at depths of 1 and 5 centimeters below the soil surface, July 19-24, 1979. 


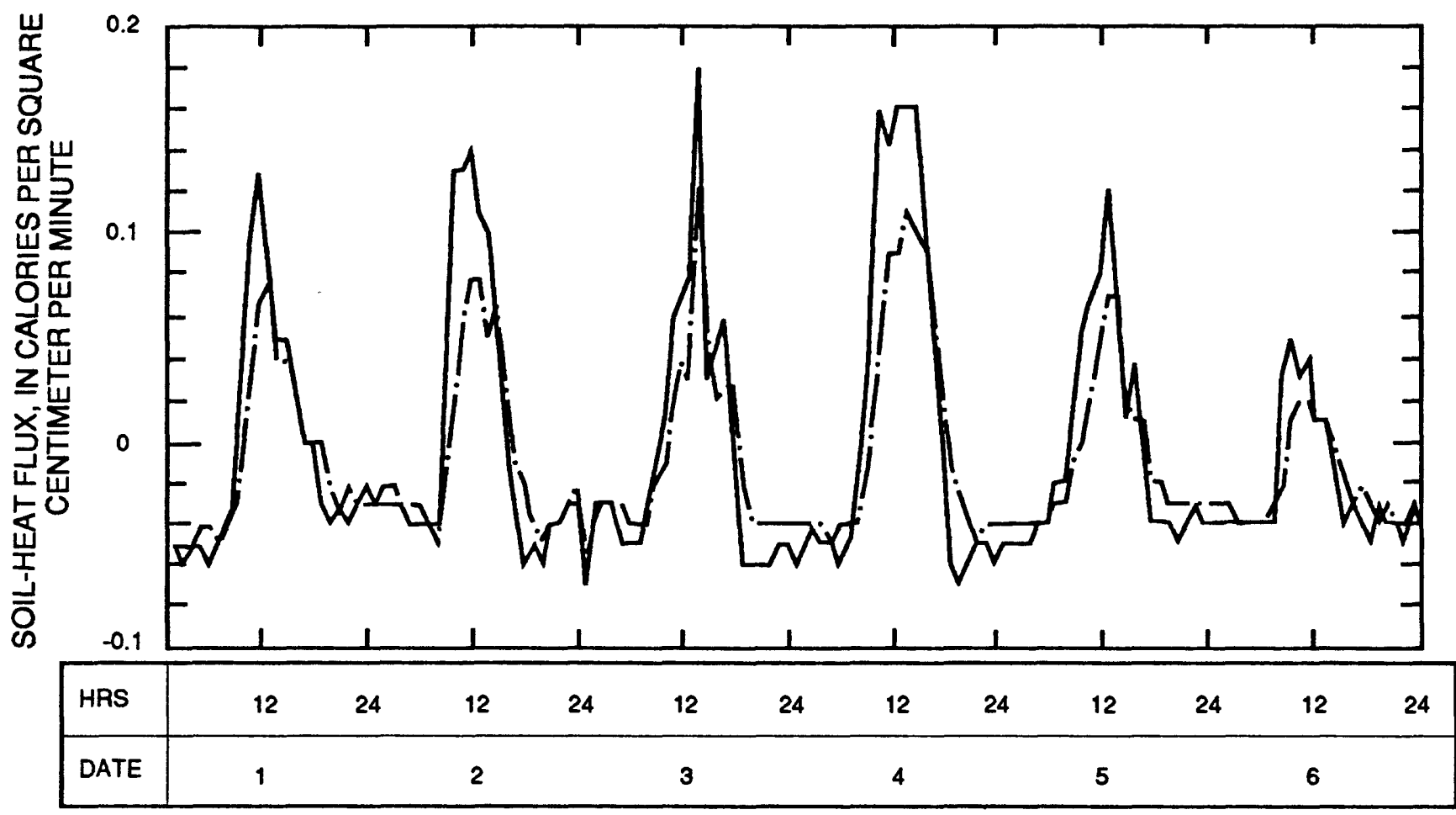

MARCH 1980

EXPLANATION

- 1 CENTIMETER - - 5 CENTIMETERS

FIGURE 13.--Hourly averaged soil-heat flux at depths of 1 and 5 centimeters below soil surface, March 1-6, 1980. 


\section{PARTIAL SOIAR ECIIPSE}

A partial solar eclipse on October 12 , 1977, was reflected in the measurements of incident solar radiation and net radiation at the study site. Instantaneous values of both incident solar radiation and net radiation recorded at 12-minute intervals for october 12, 1977, are shown in figure 14. The partial solar eclipse began at about 1200 hours and reached a maximum at about 1310 hours. It lasted approximately 2 hours and 15 minutes, ending at about 1415 hours. The effects of the eclipse on both incident solar and net radiation are demonstrated by figure 14 . The values of incident solar radiation and net radiation reached peaks at 1200 hours with $1.04\left(\mathrm{cal} / \mathrm{cm}^{2}\right) / \mathrm{min}$ and $0.71\left(\mathrm{cal} / \mathrm{cm}^{2}\right) / \mathrm{min}$, respectively. Incident solar radiation subsequently dropped to $0.75\left(\mathrm{cal} / \mathrm{cm}^{2}\right) / \mathrm{min}$ during the partial eclipse, a reduction of $0.29\left(\mathrm{cal} / \mathrm{cm}^{2}\right) / \mathrm{min}$, or 28 percent. Net radiation dropped to $0.41\left(\mathrm{cal} / \mathrm{cm}^{2}\right) / \mathrm{min}$, a reduction of $0.30\left(\mathrm{cal} / \mathrm{cm}^{2}\right) / \mathrm{min}$, or 42 percent.

1.0

$-$

\section{$\longmapsto$ PARTIAL SOLAR
ECLIPSE \\ $\longmapsto$ PARTIAL SOLAR
ECLIPSE}

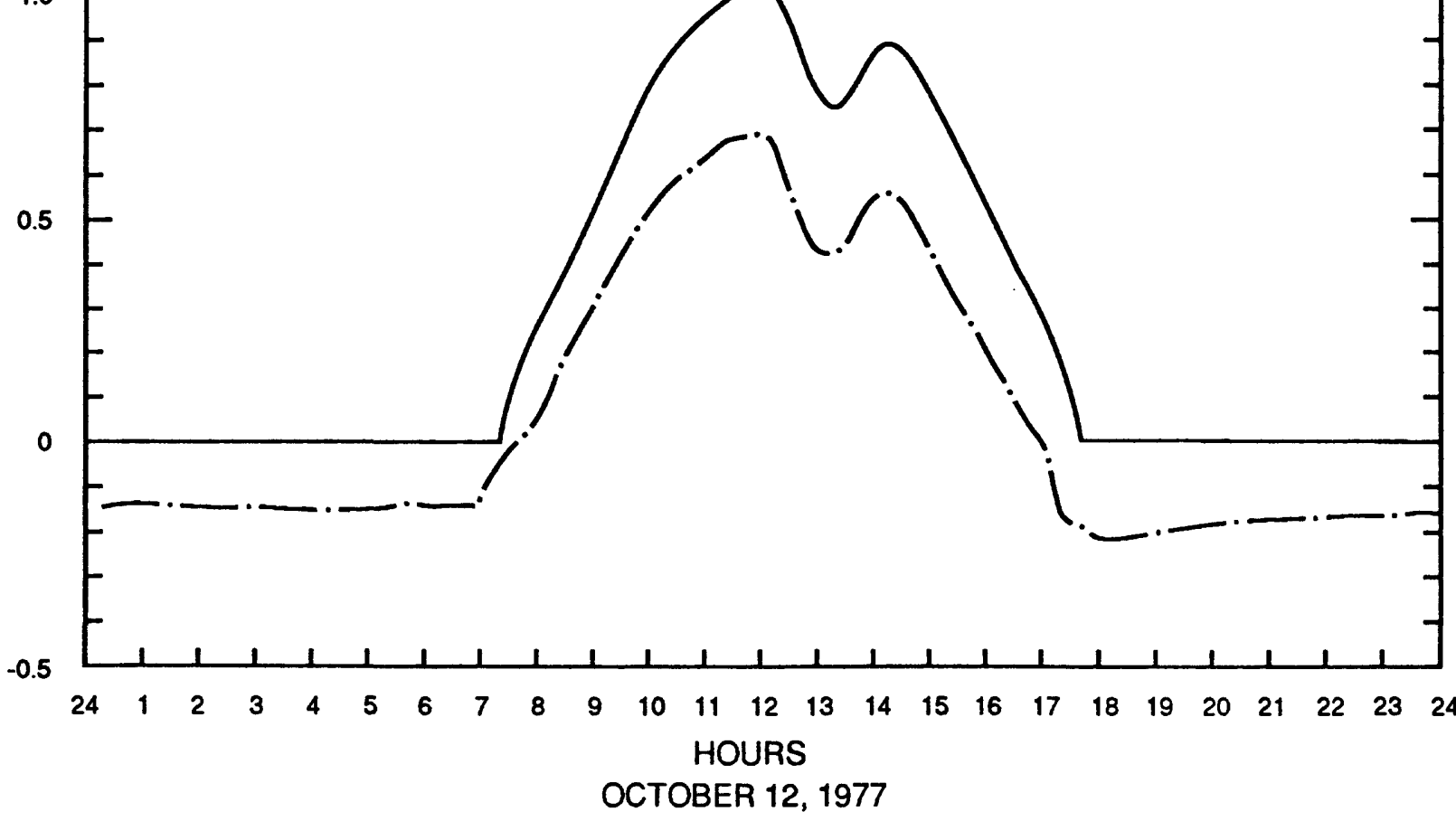

EXPLANATION

FIGURE 14.--Incident solar radiation and net radiation, october 12, 1977. 
Instantaneous values of temperature of the flat-plate net radiometer and the dry- and wet-bulb air temperatures recorded at 12-minute intervals on October 12, 1977, are shown in figure 15. Temperature of the flat-plate net radiometer decreased between about 1200 and 1300 hours from $34{ }^{\circ} \mathrm{C}$ to $32{ }^{\circ} \mathrm{C}$. The $\mathrm{dry}$ - and wet-bulb air tempera-ture, like the temperature of the flat-plate radiometer, also decreased during this period but with a much steeper initial decline.

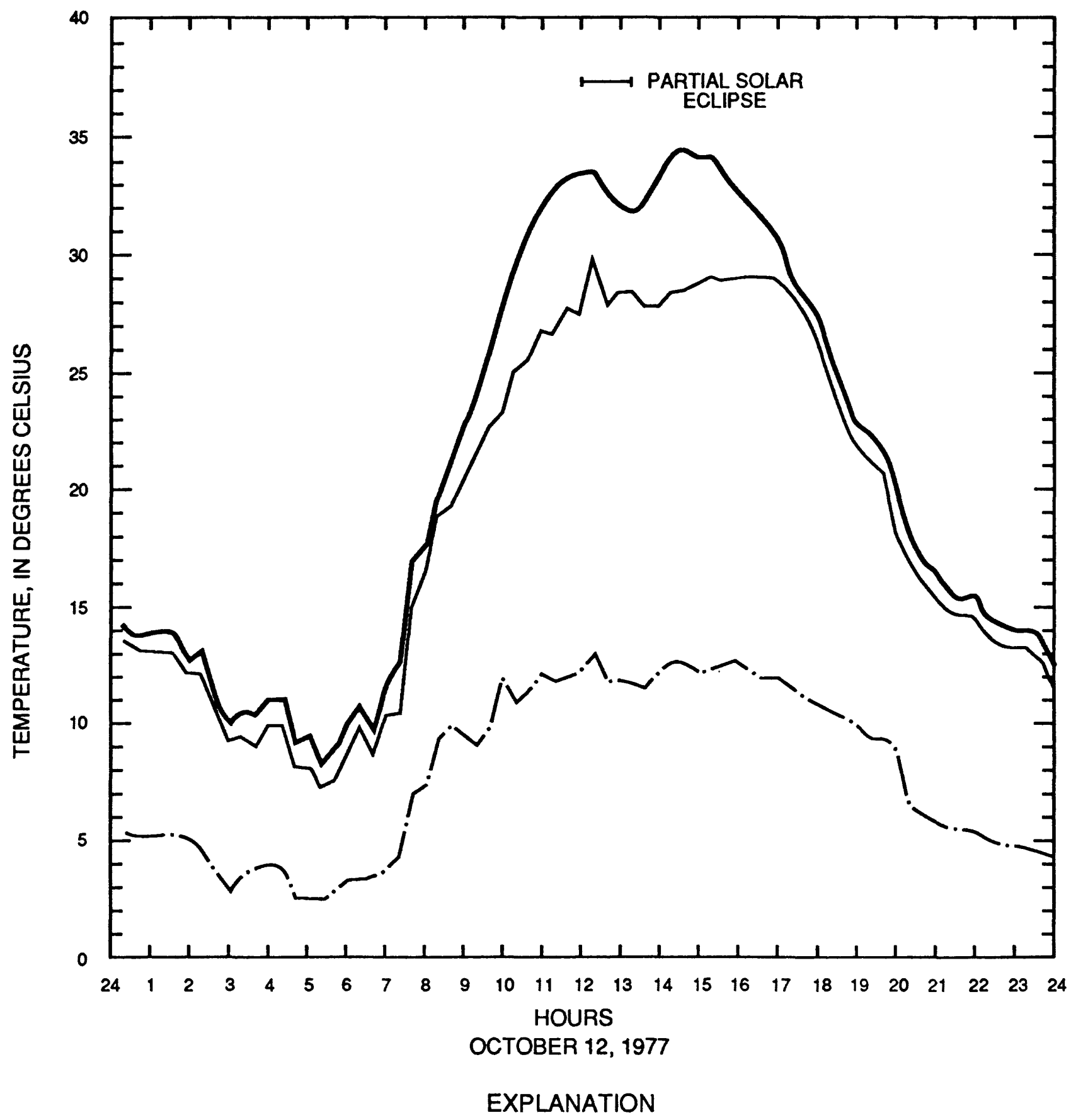

\section{FLAT-PLATE NET RADIOMETER TEMPERATURE}

FIGURE 15.--Comparison of temperature from flat-plate net radiometer with dry- and wet-bulb air temperatures at height of 100 centimeters above soil surface, October 12, 1977. 
Meteorological data were collected from November 1977 to May 1980 at the radioactive-waste-burial facility near Beatty in southern Nevada. This report provides total daily precipitation and daily averaged values of windspeed and wind direction; incident solar radiation; reflected solar radiation; dry- and wet-bulb air temperatures at heights of 50 , 100 , and $200 \mathrm{~cm}$ above the soil surface; relative humidity; soil temperatures at depths of $1,5,10,30$, and $100 \mathrm{~cm}$ below the soil surface; soil-heat flux at depths of 1,5 , and $10 \mathrm{~cm}$; and a general description of the methods and instruments used to collect them. On the basis of limited wind data, averaged daily windspeed ranged from less than 1 to almost $34 \mathrm{~m} / \mathrm{s}$ and direction was predominantly from the south and west. The smaller difference between dry- and wet-bulb air temperatures during the wet season, January through April, indicated higher humidity compared to the dry season, May through December. Solar radiation, dryand wet-bulb air temperatures, soil temperature, and soil-heat flux also showed diurnal fluctuations. A partial solar eclipse on october 12, 1977, at the study site, affected air temperature and incident solar and net radiation.

\section{REEERTNCE CITED}

Nichols, W.D., 1987, Geohydrology of the unsaturated zone at the burial site for low-level radioactive waste near Beatty, Nye County, Nevada: U.S. Geological Survey Water-Supply Paper 2312, 57 p. 


\section{BASIC DATA}

This section contains table 1 , which is a listing of daily averaged meteorological data (except precipitation, which is totaled) collected at the study site for the period November 1977 throught May 1980 . 


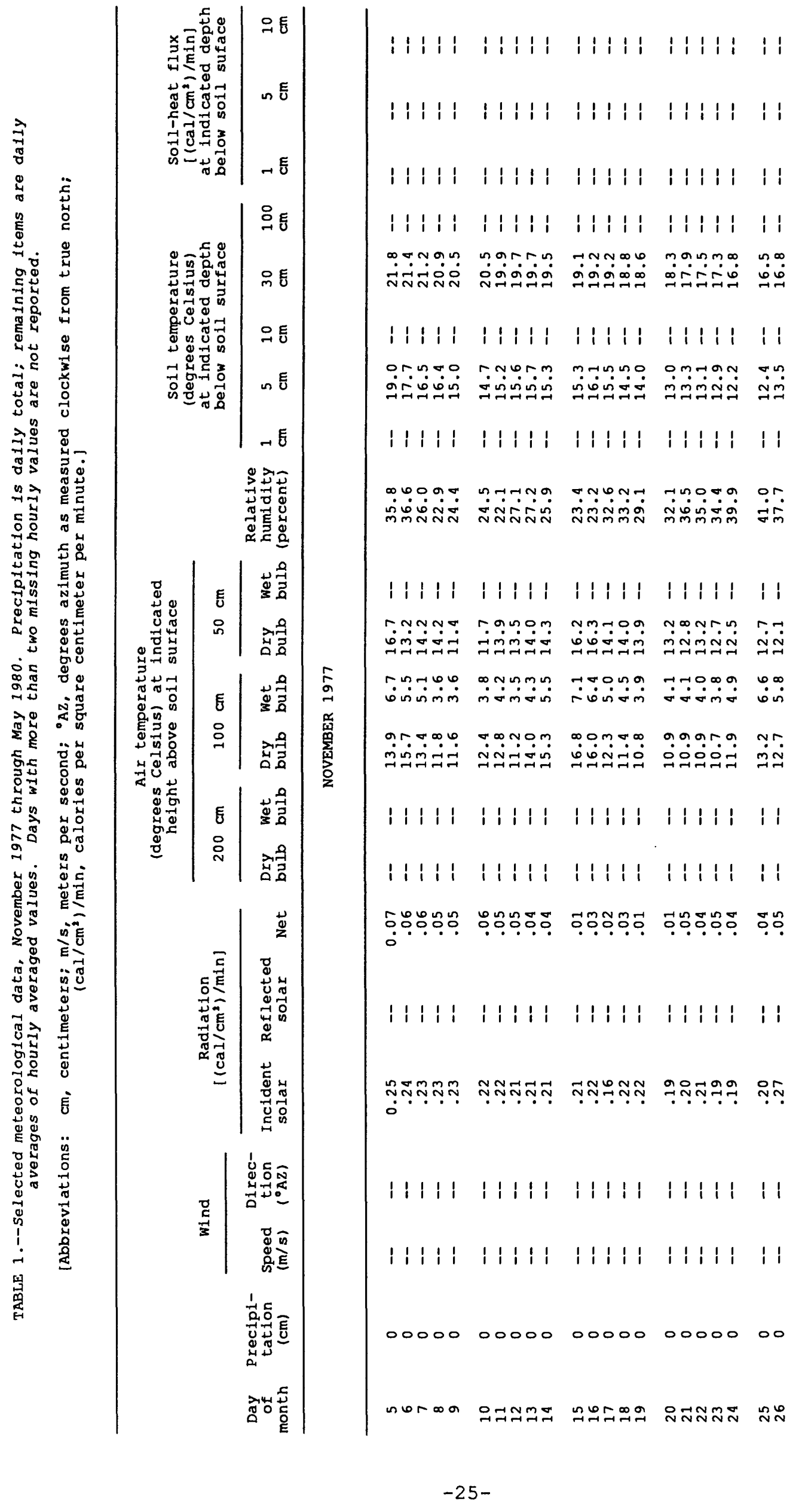




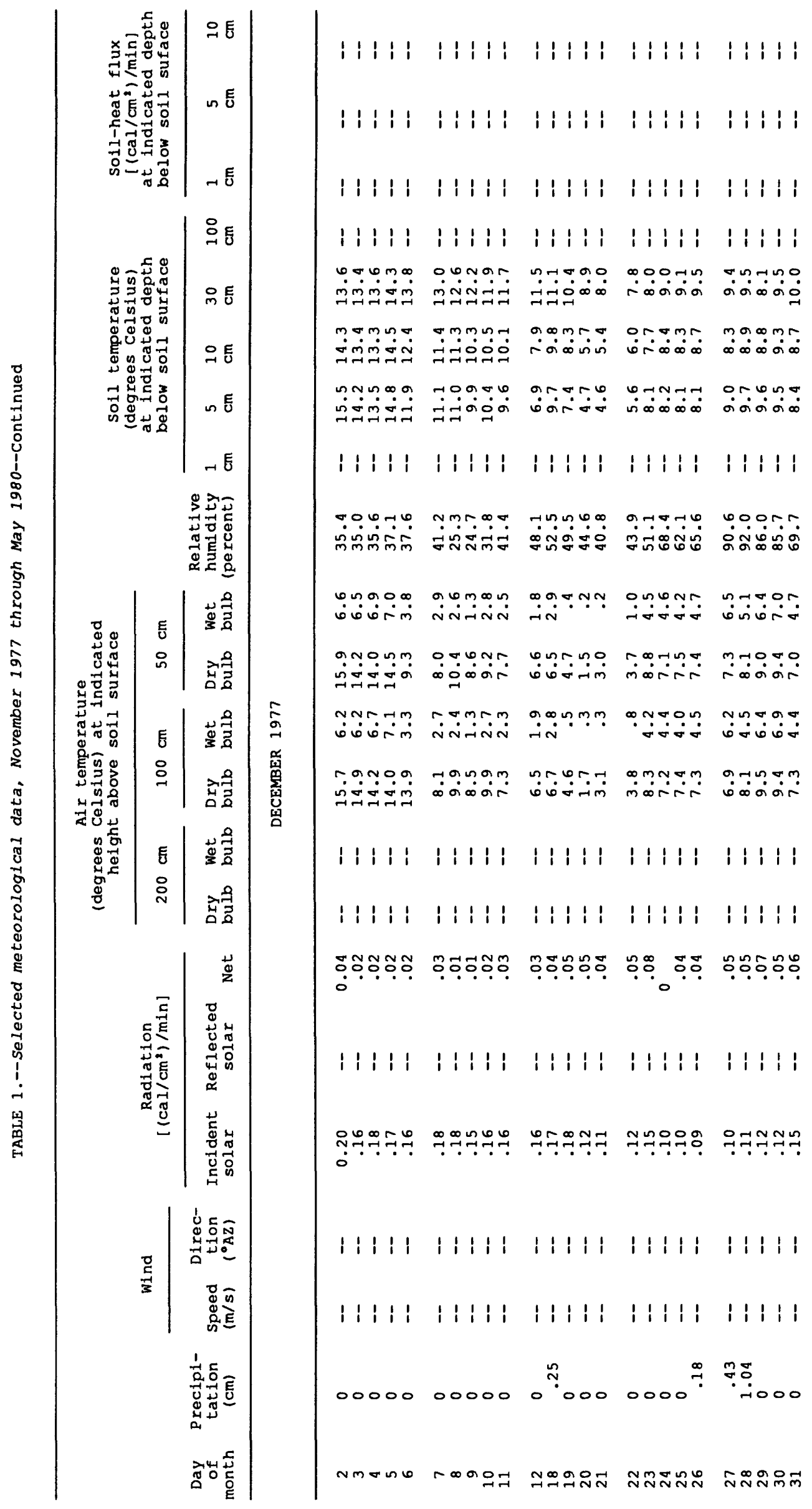




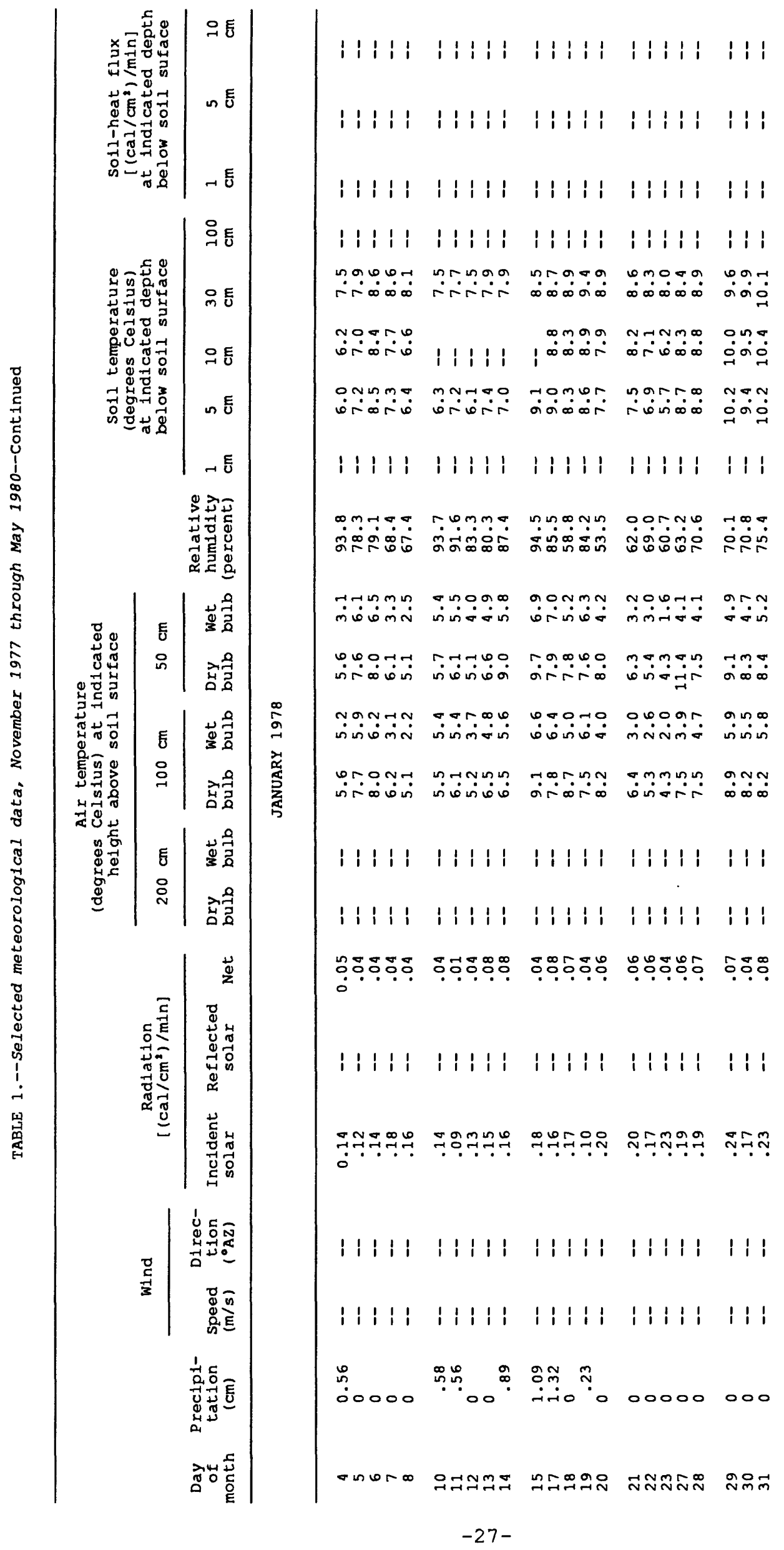




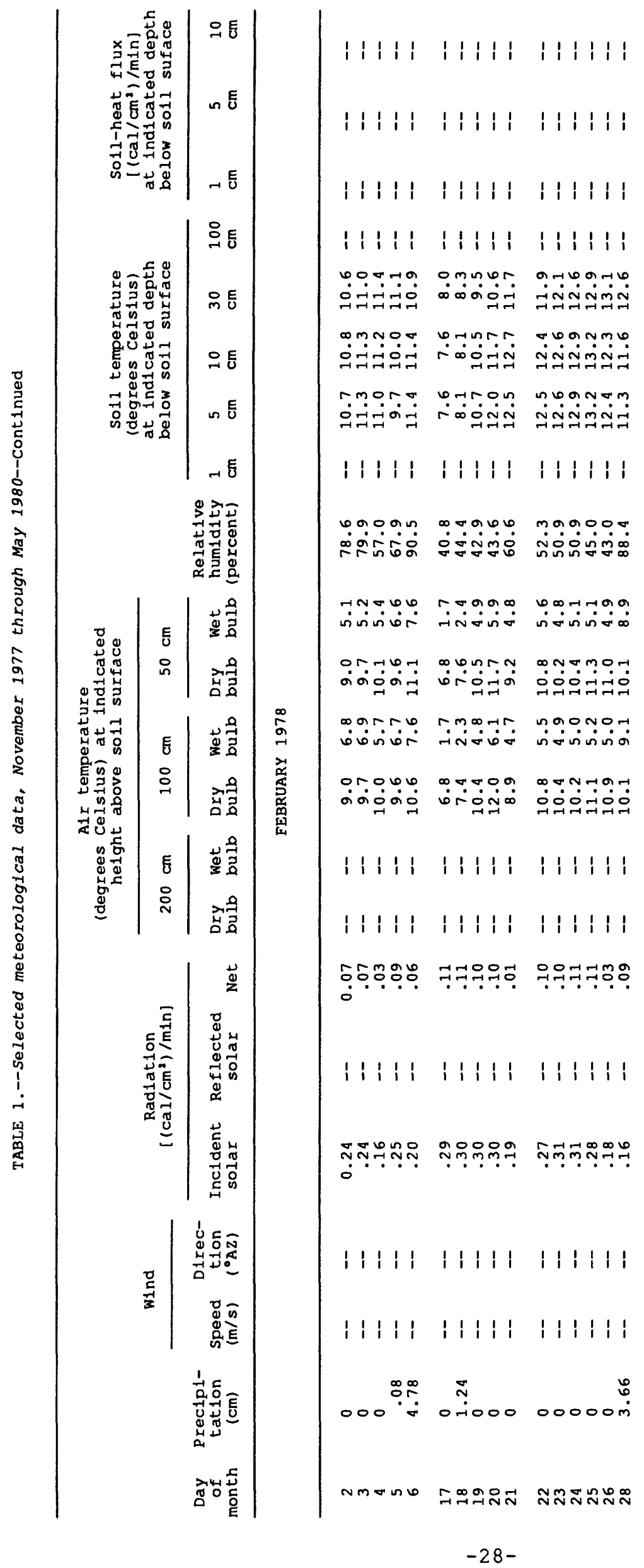




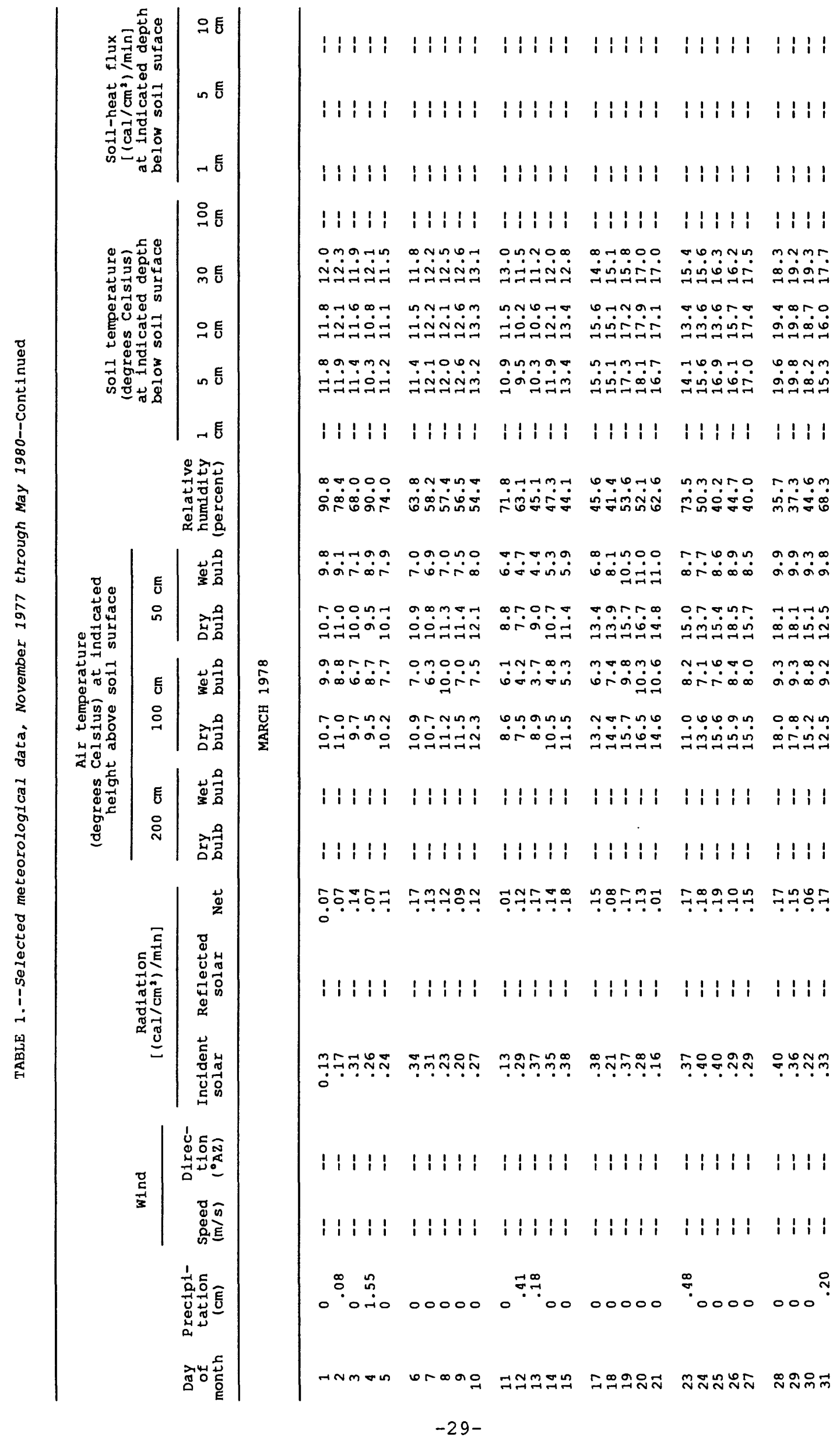




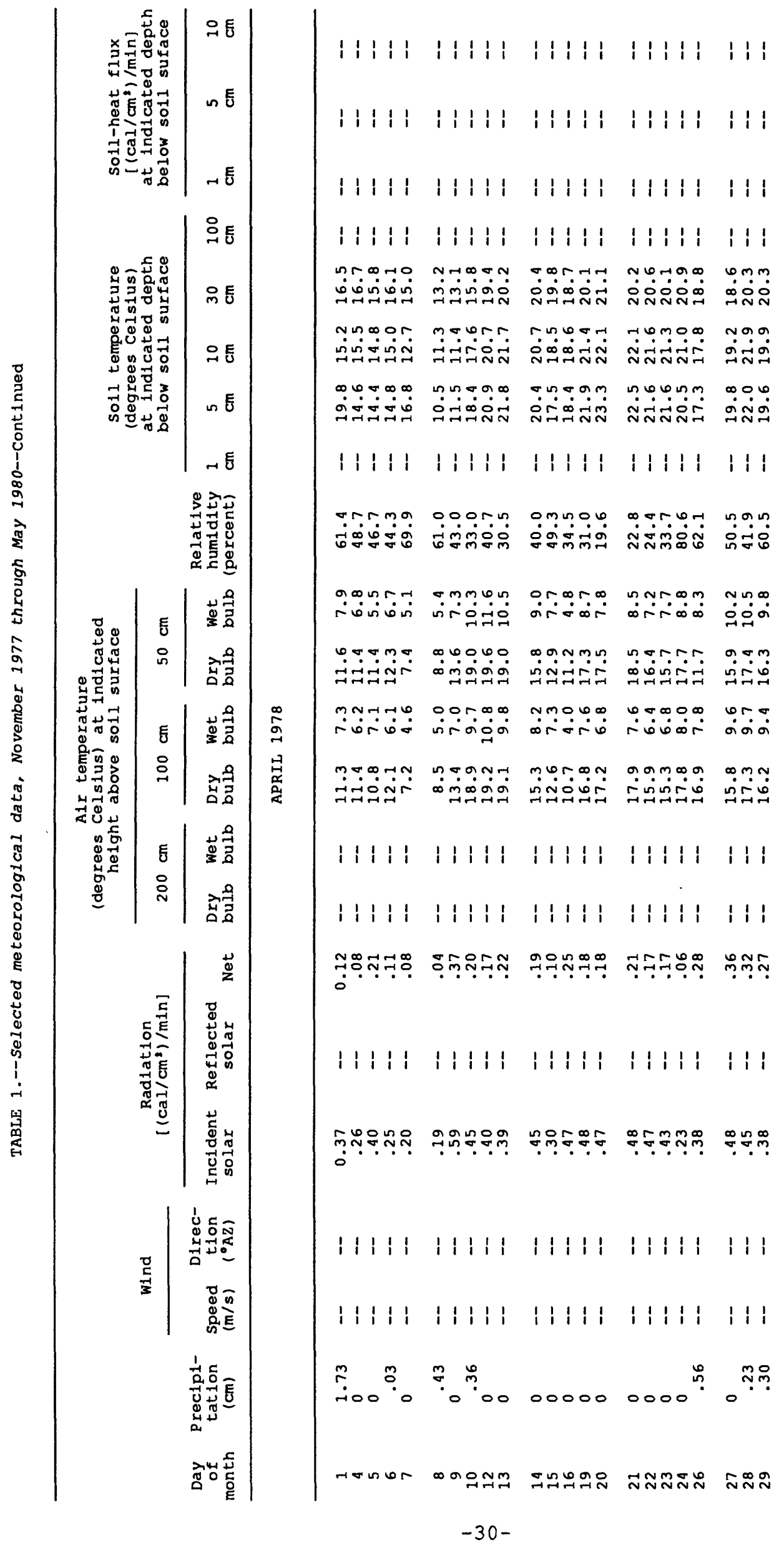




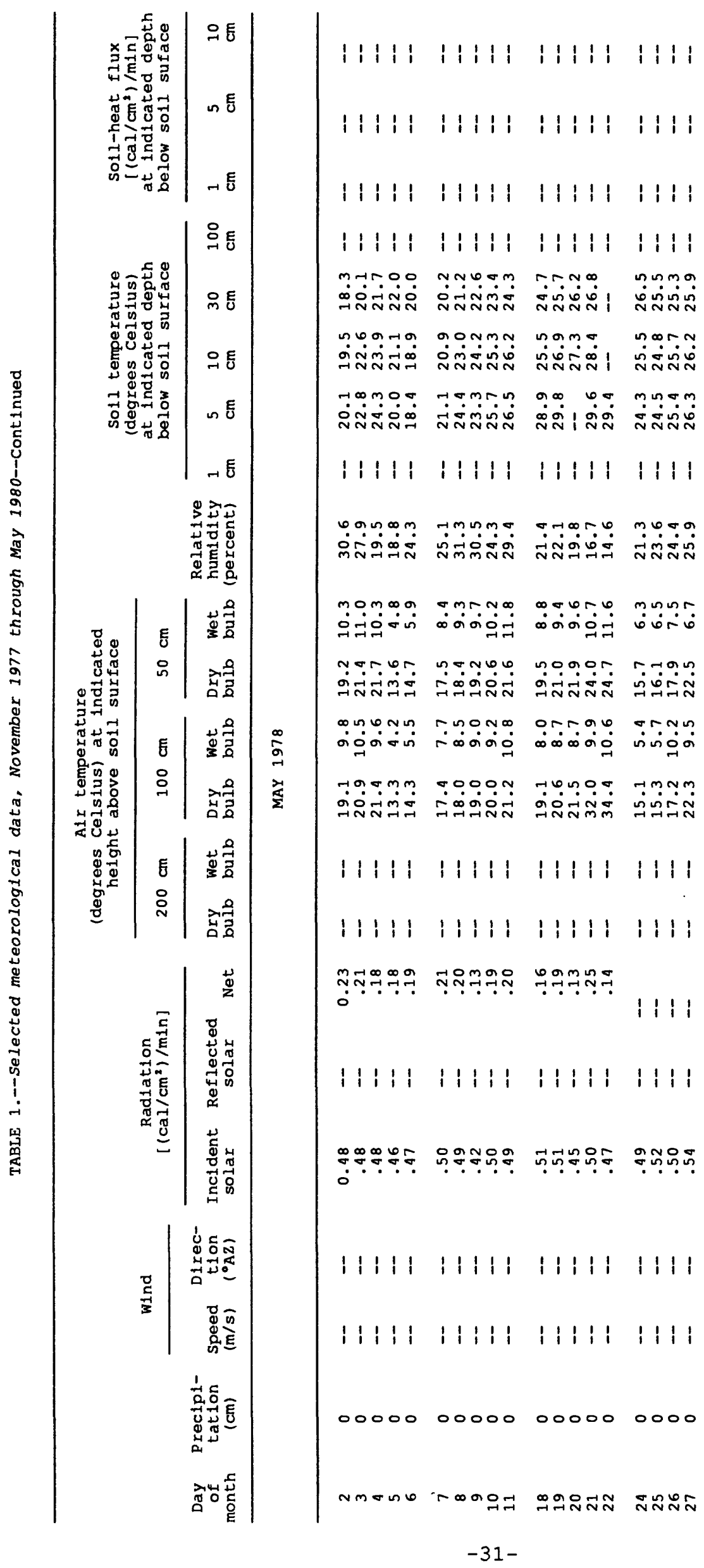




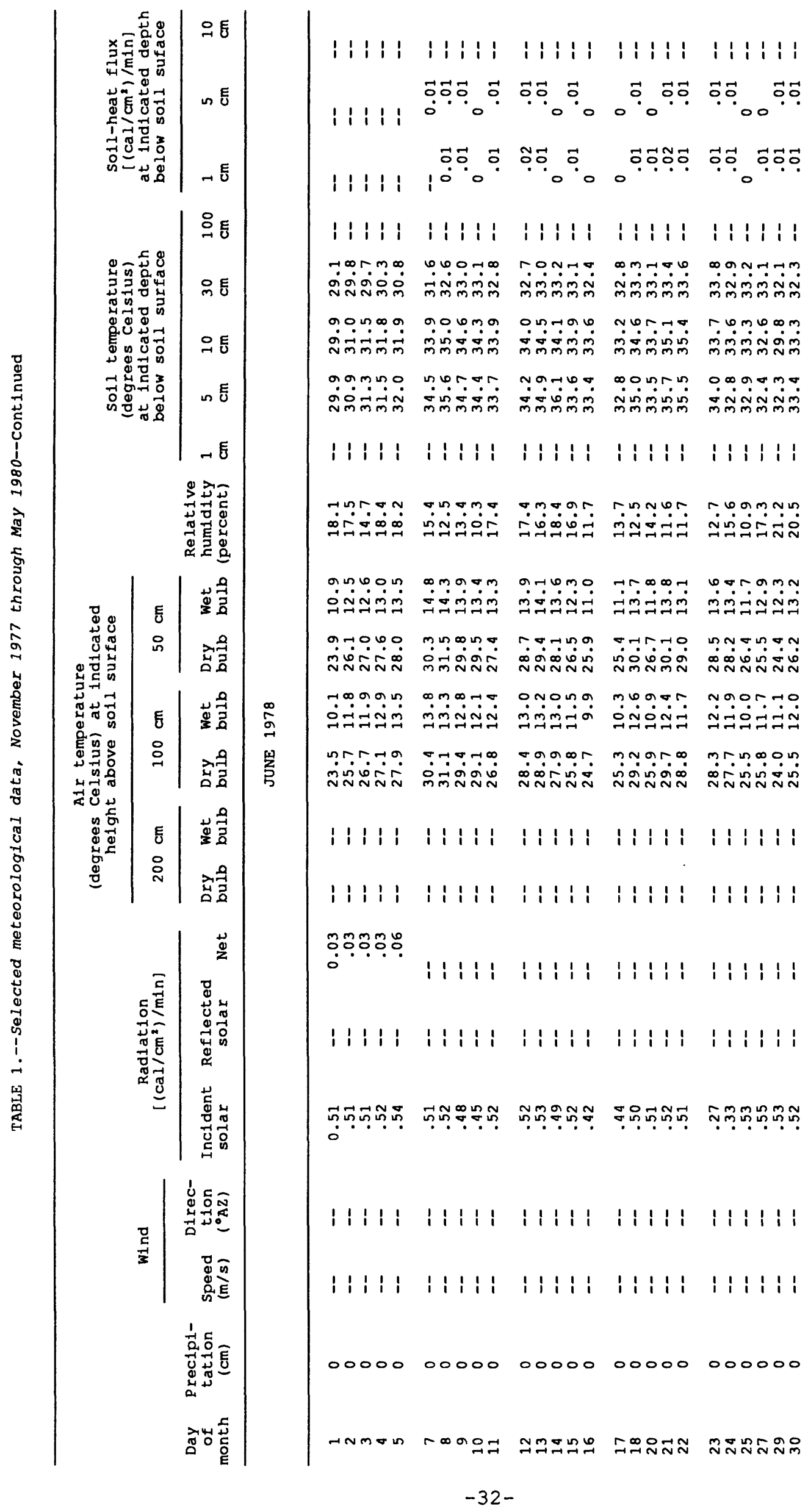




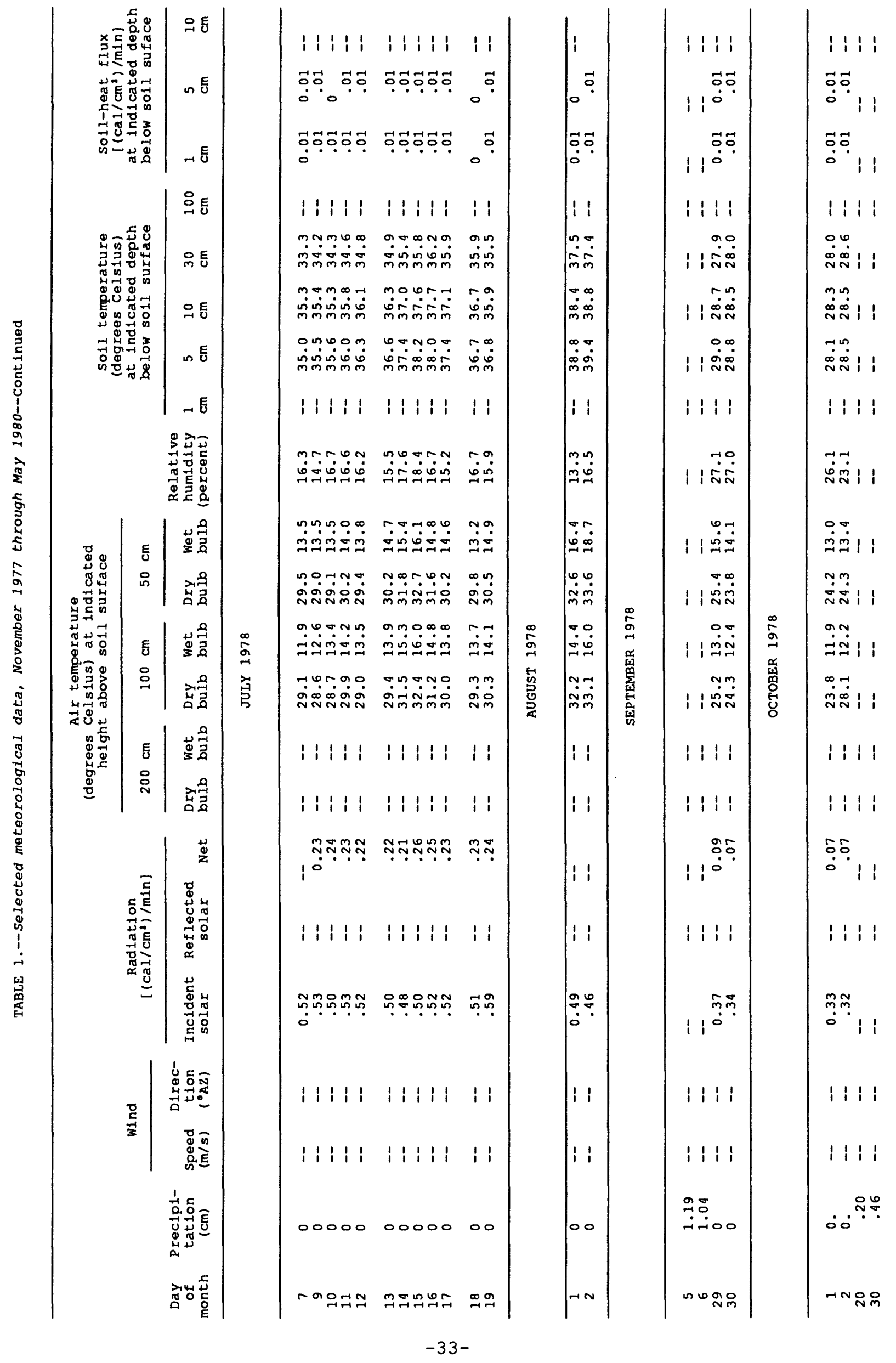




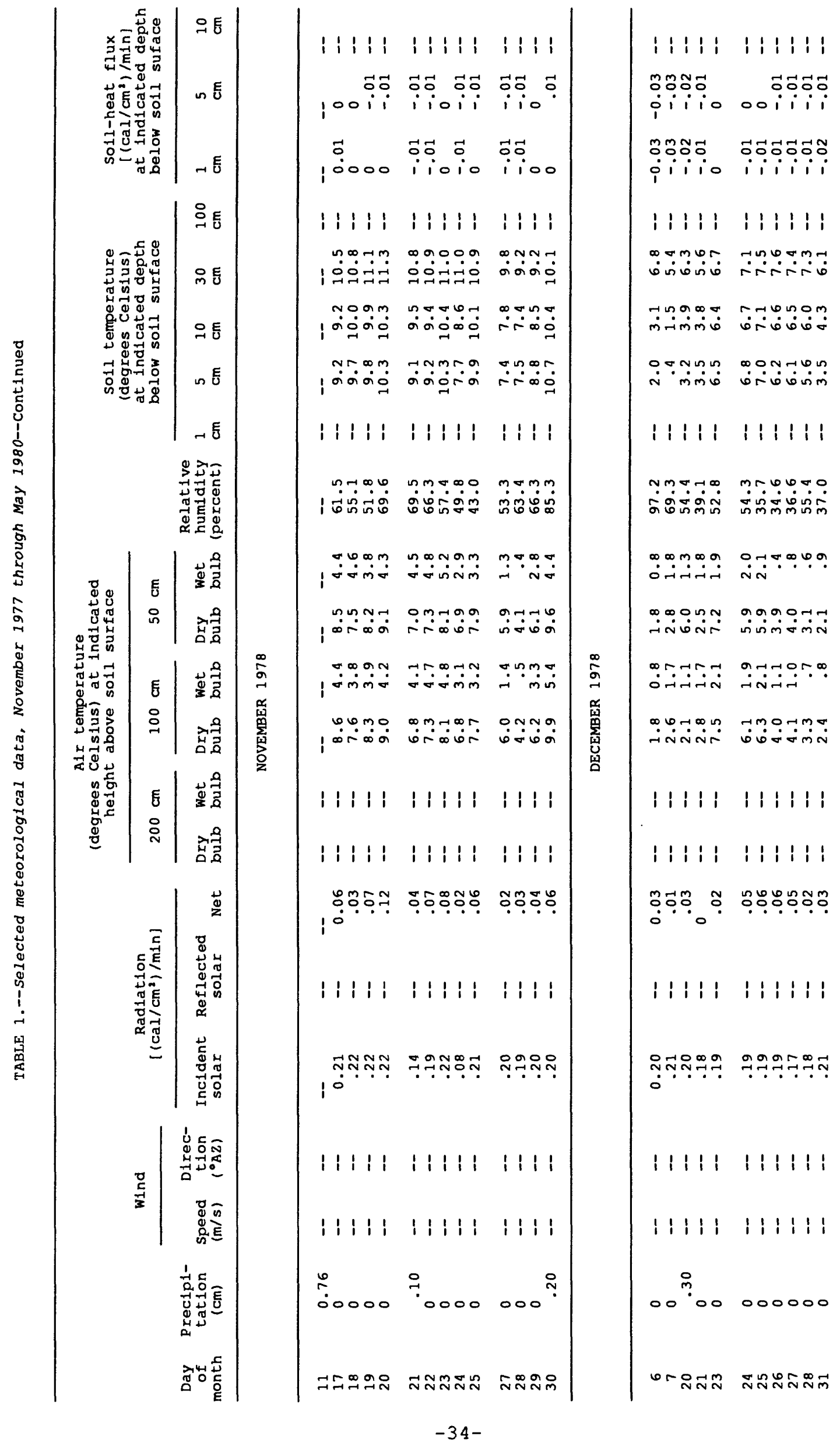




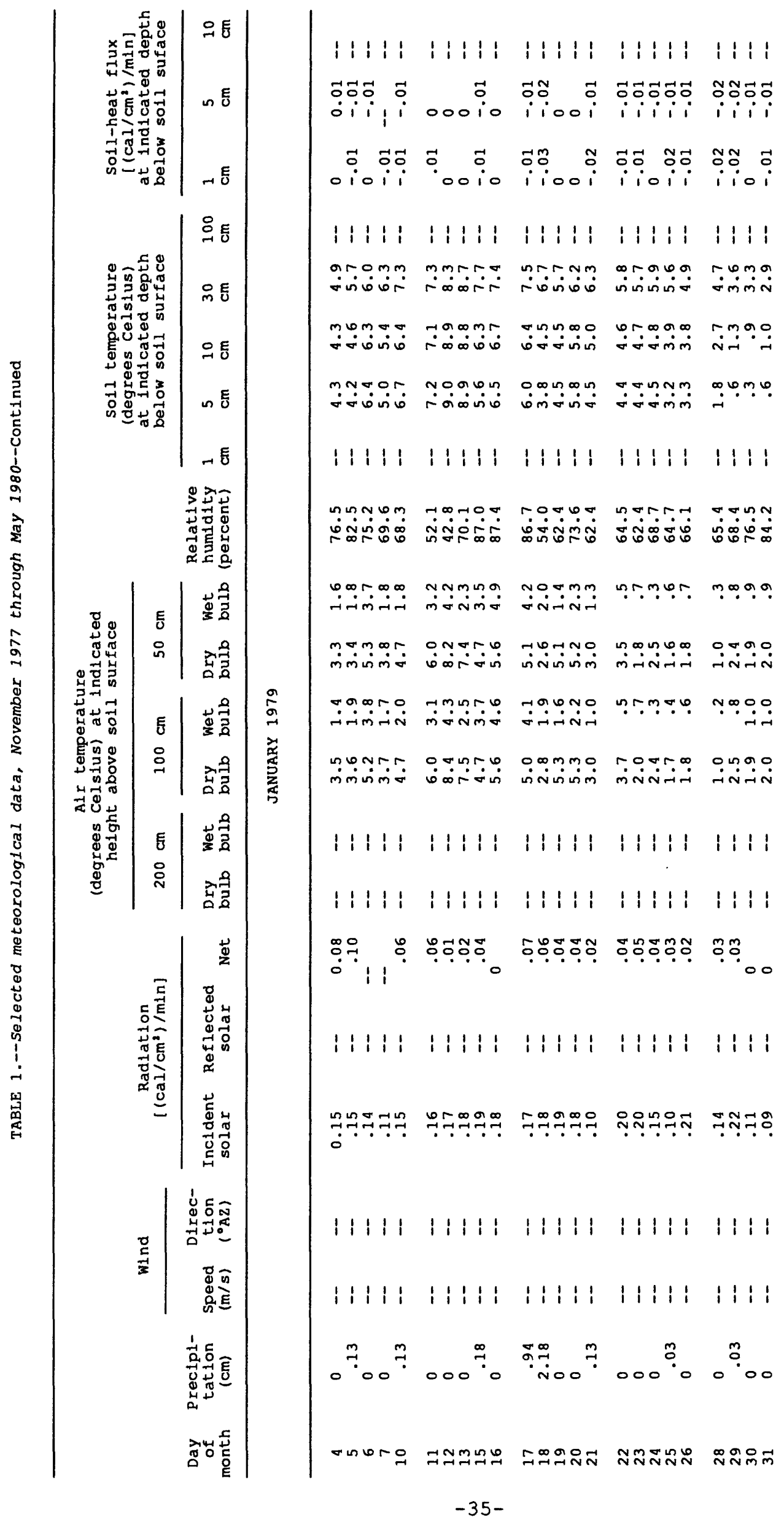




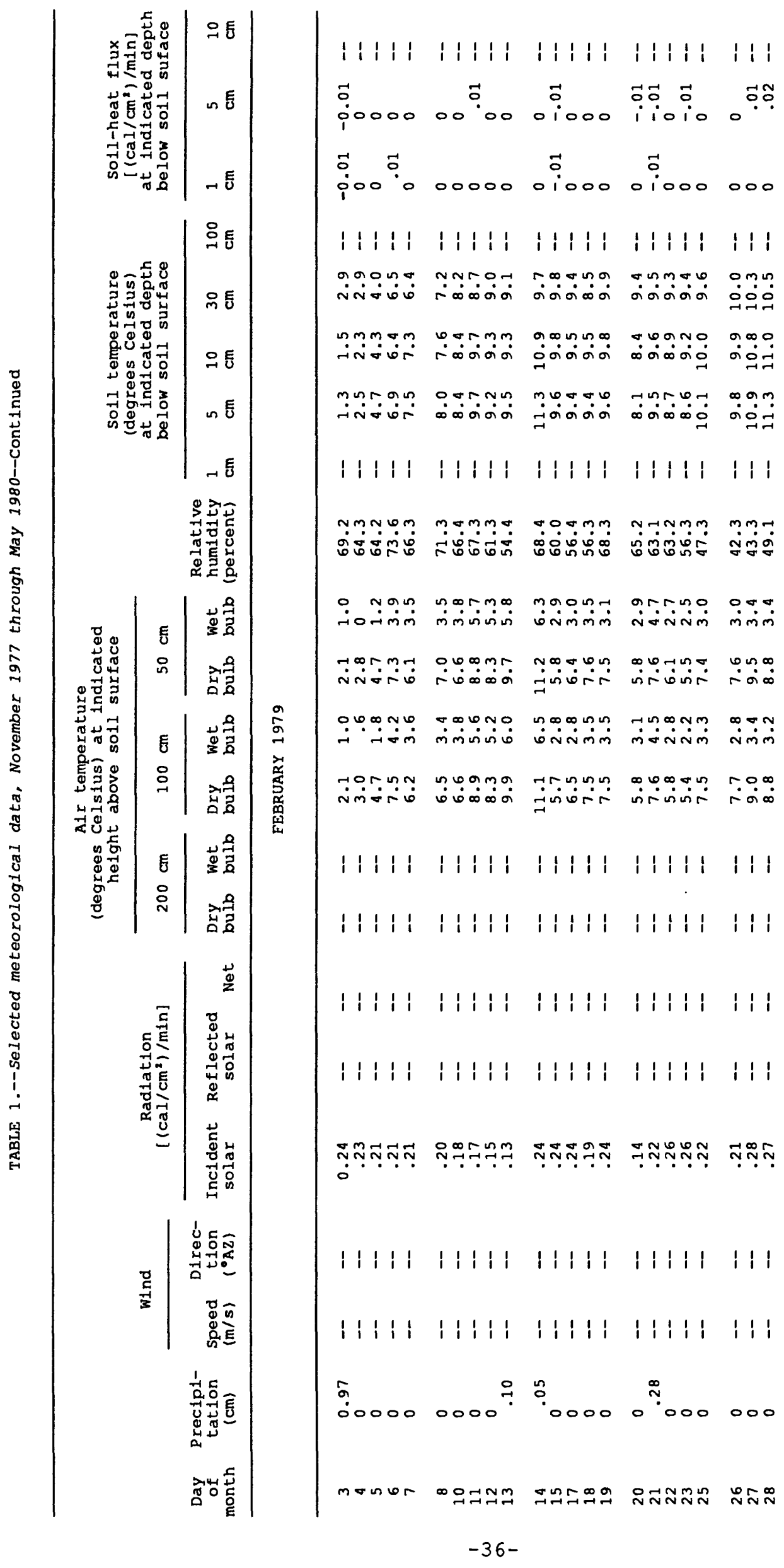




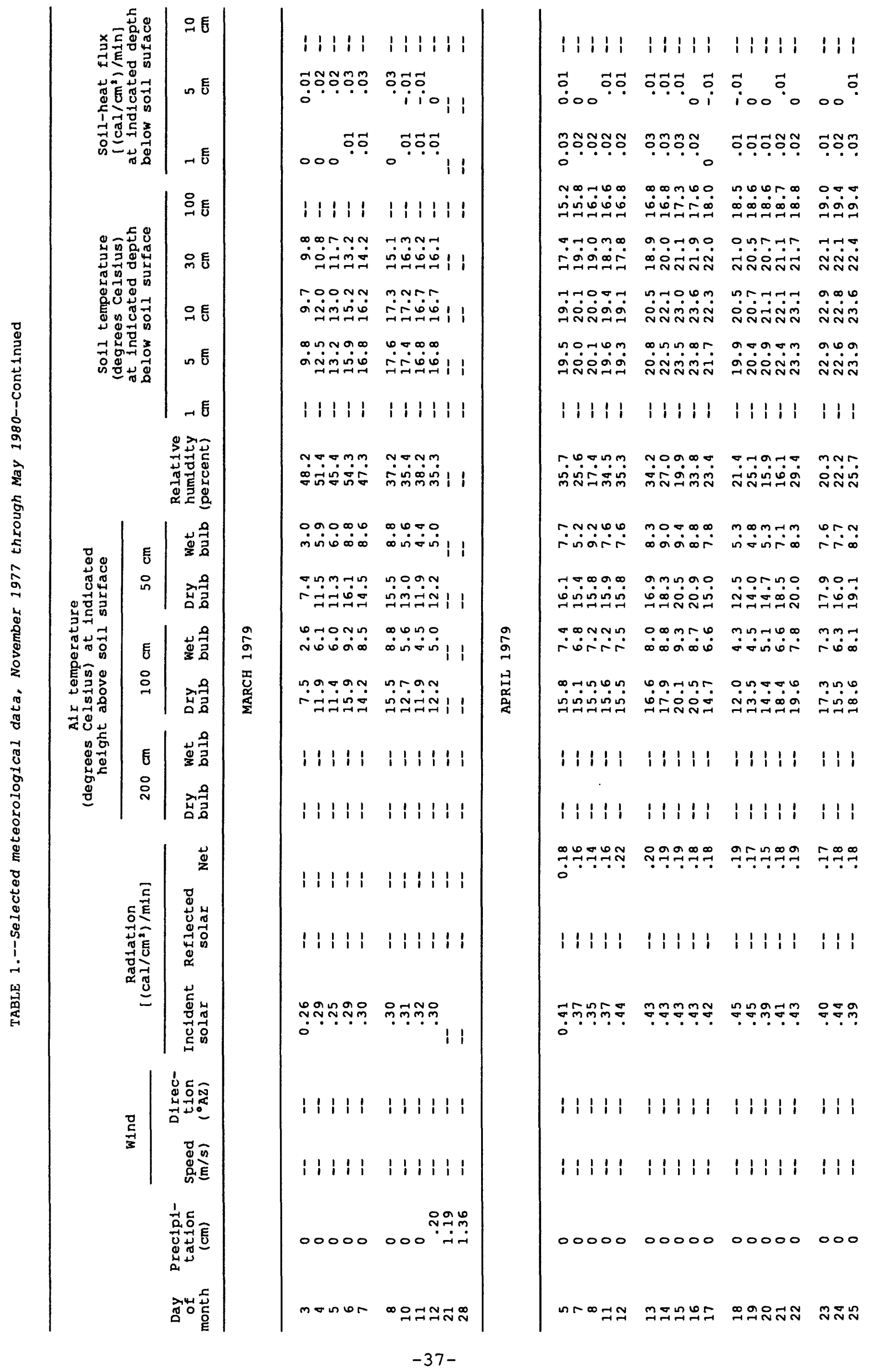




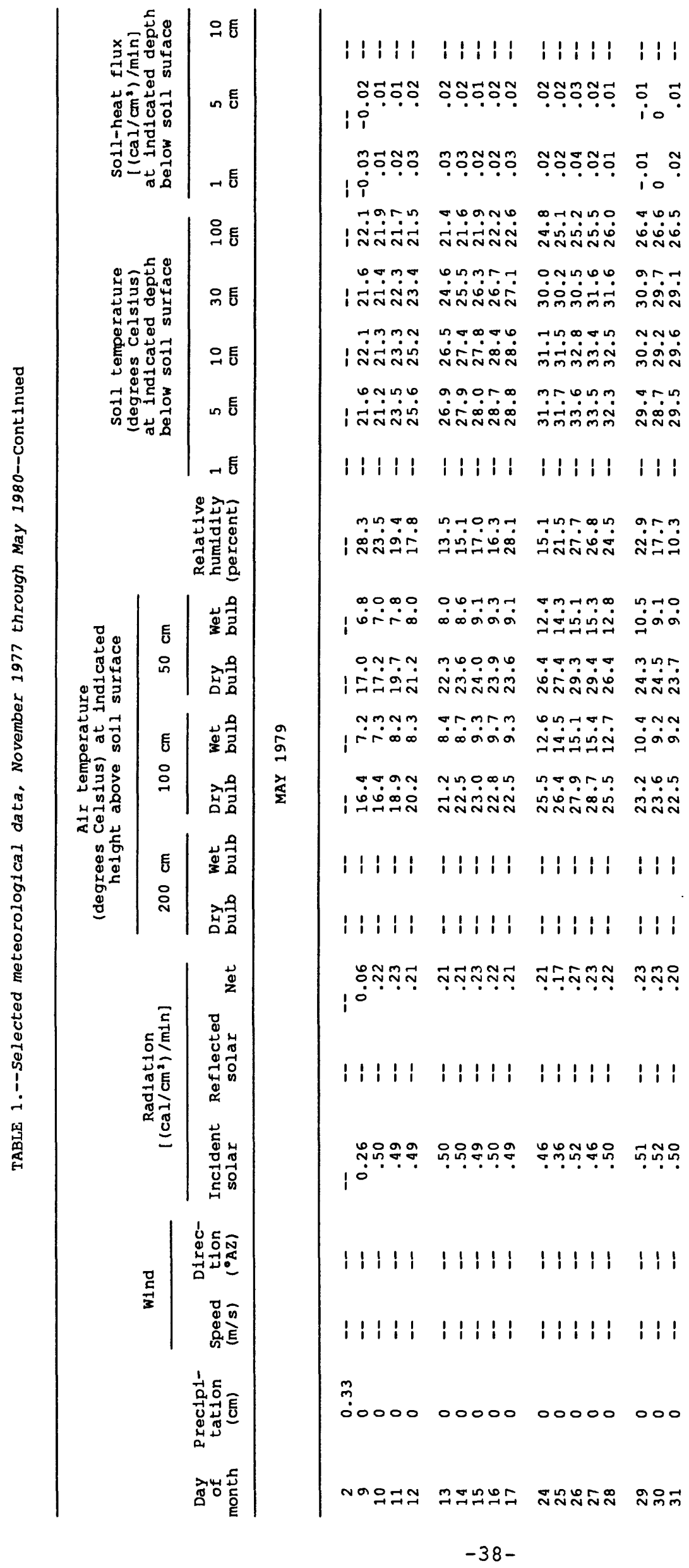




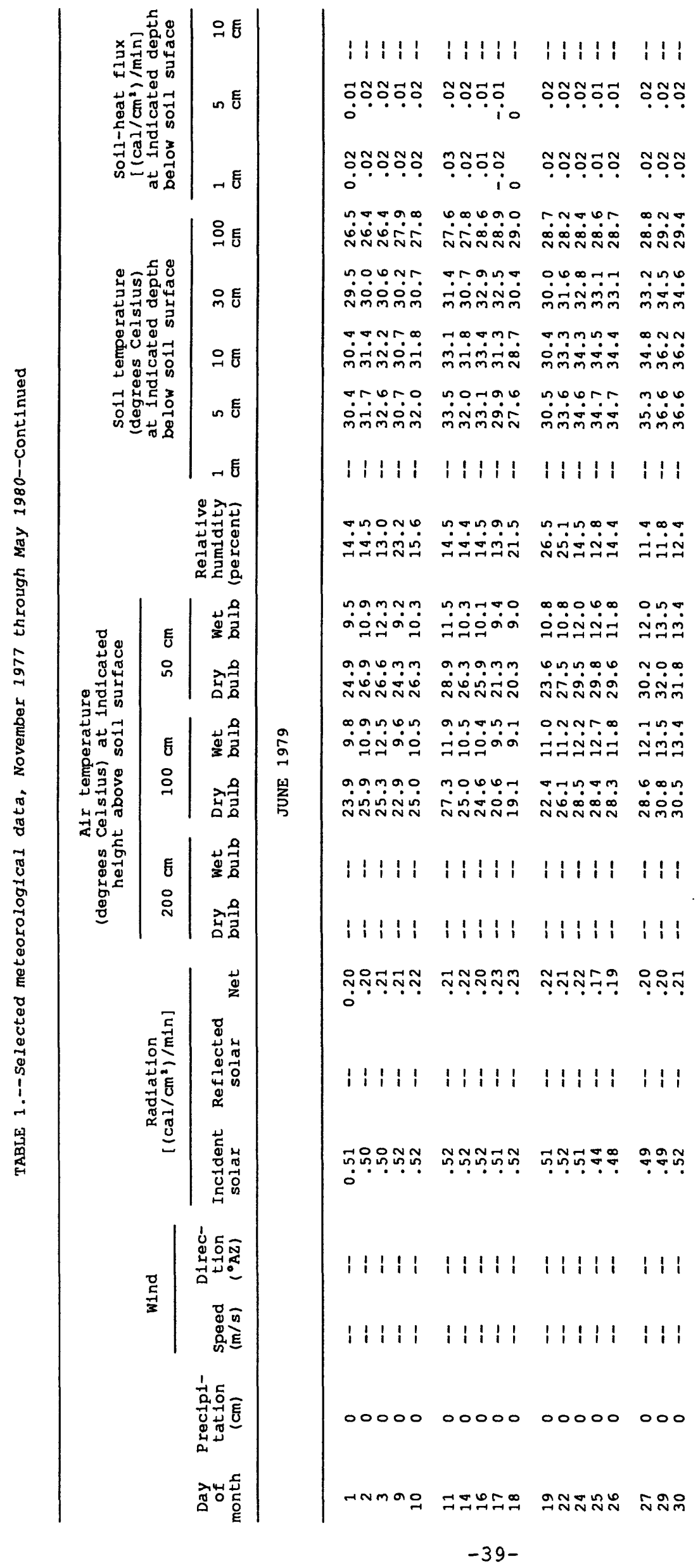




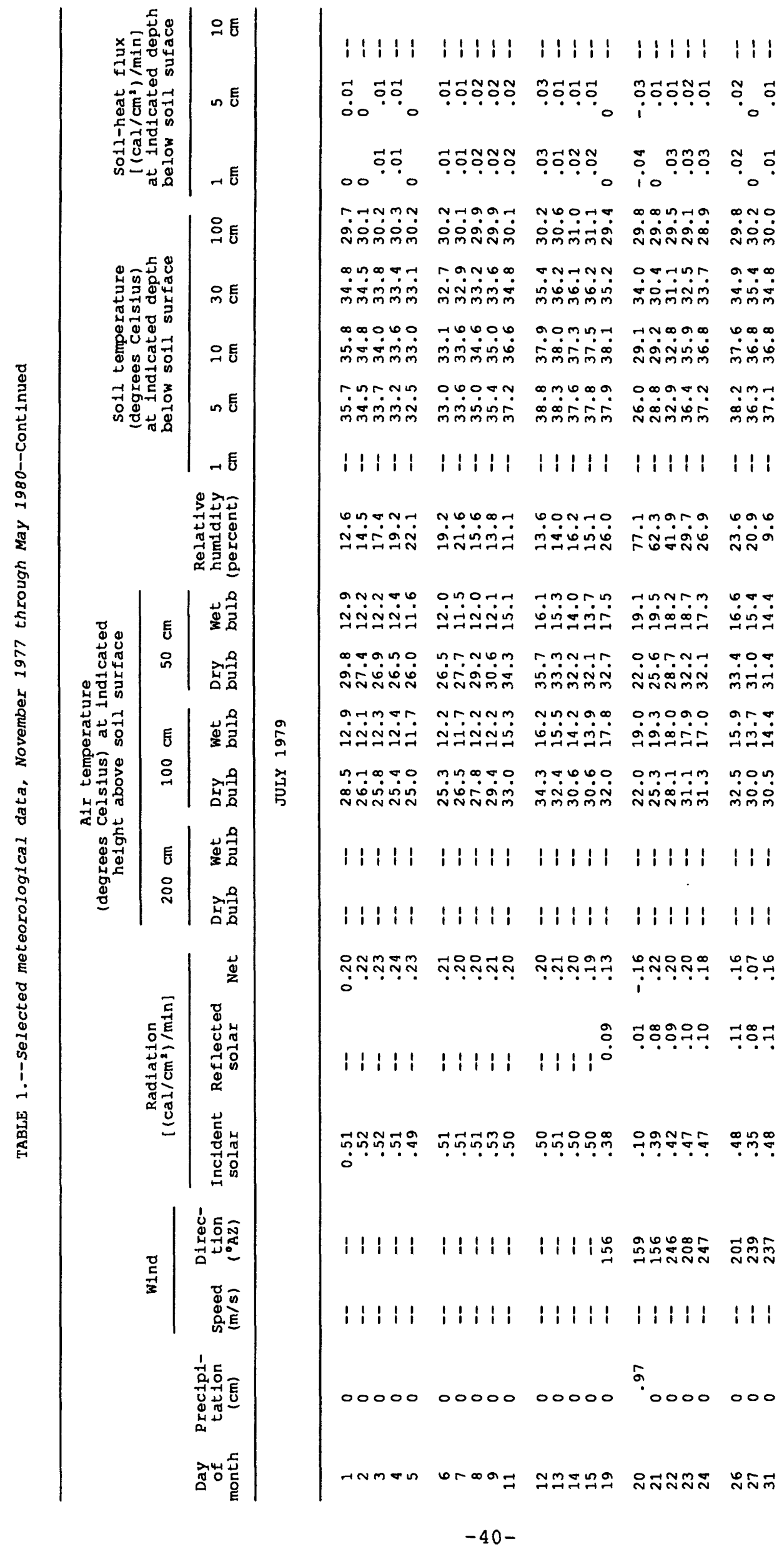




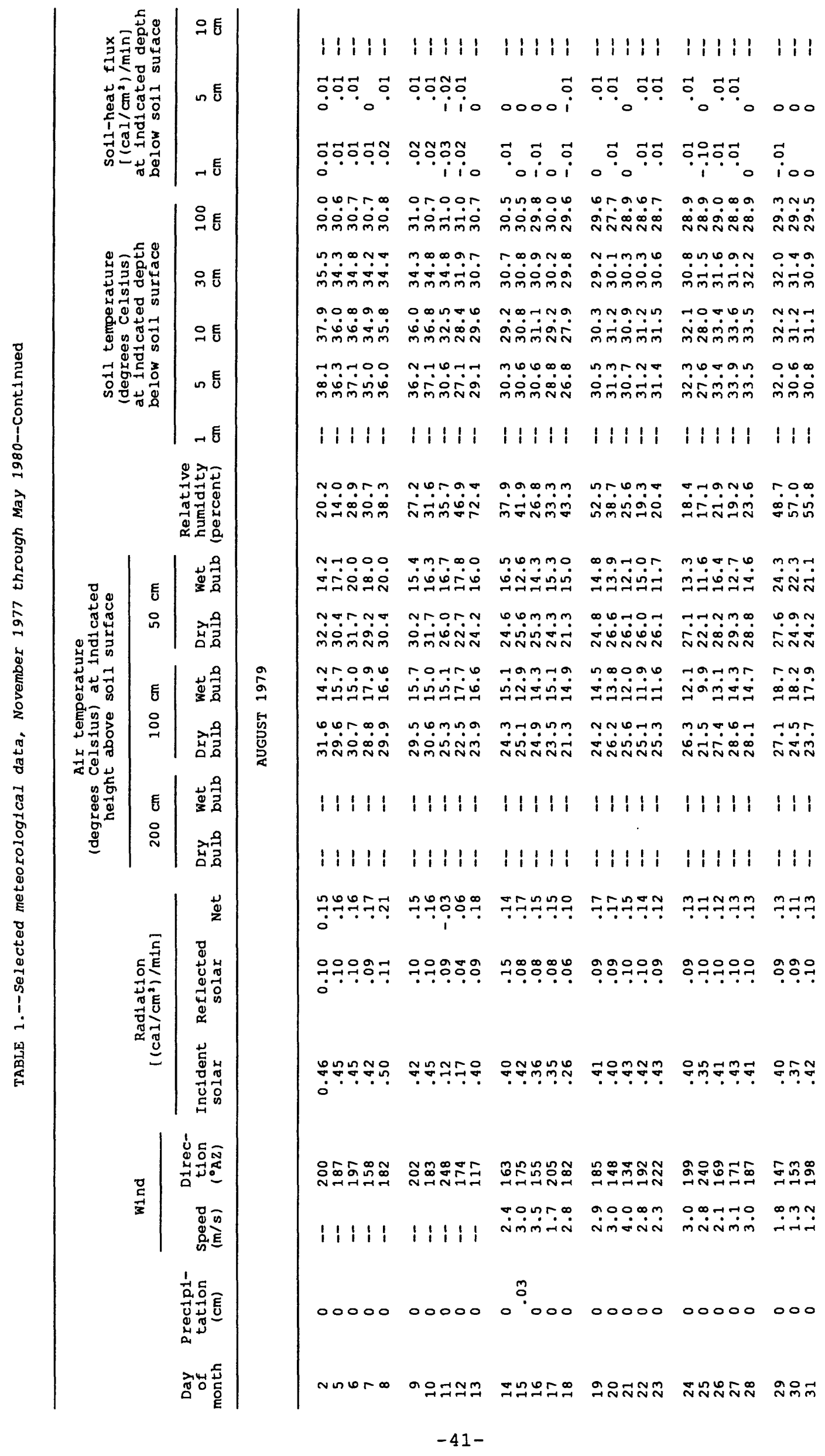




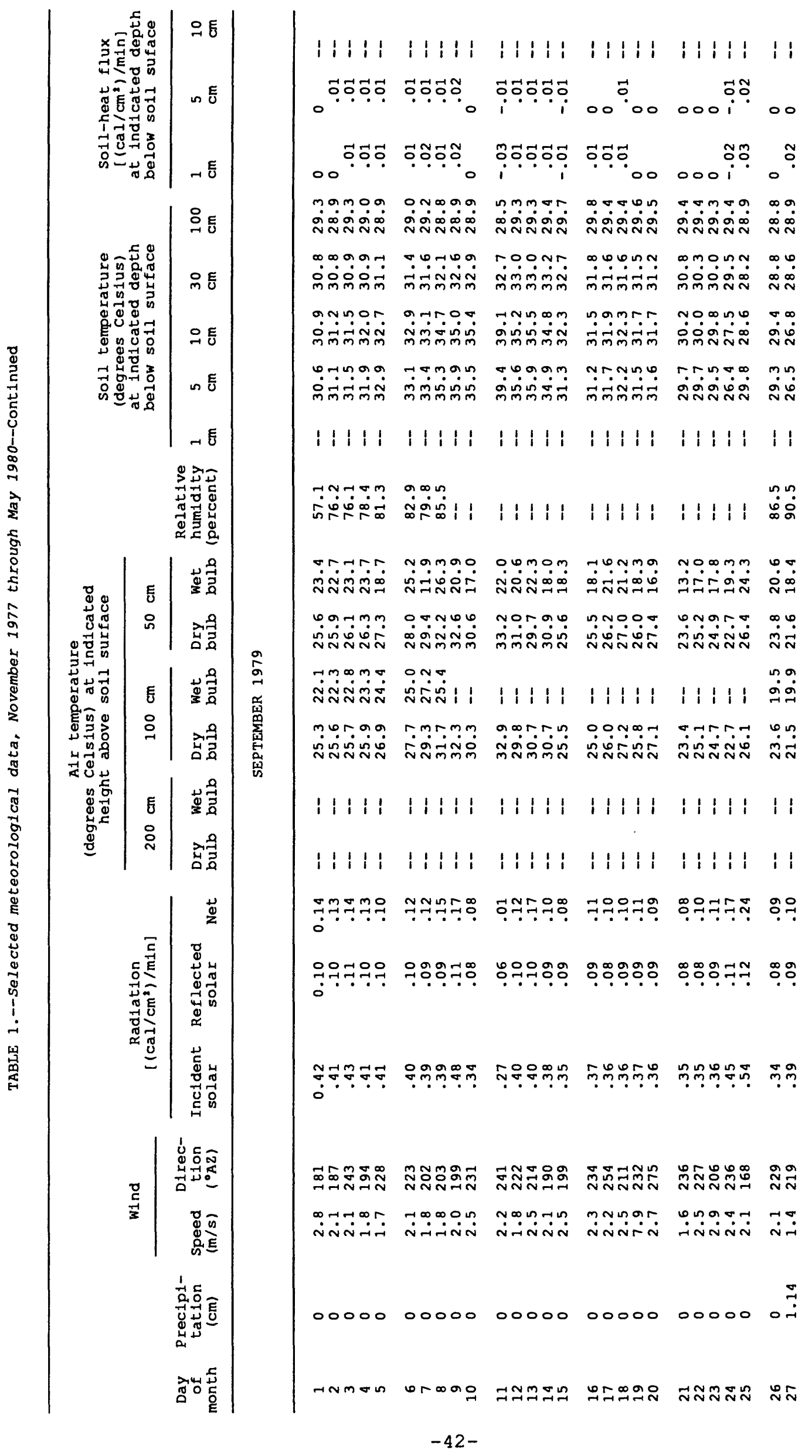




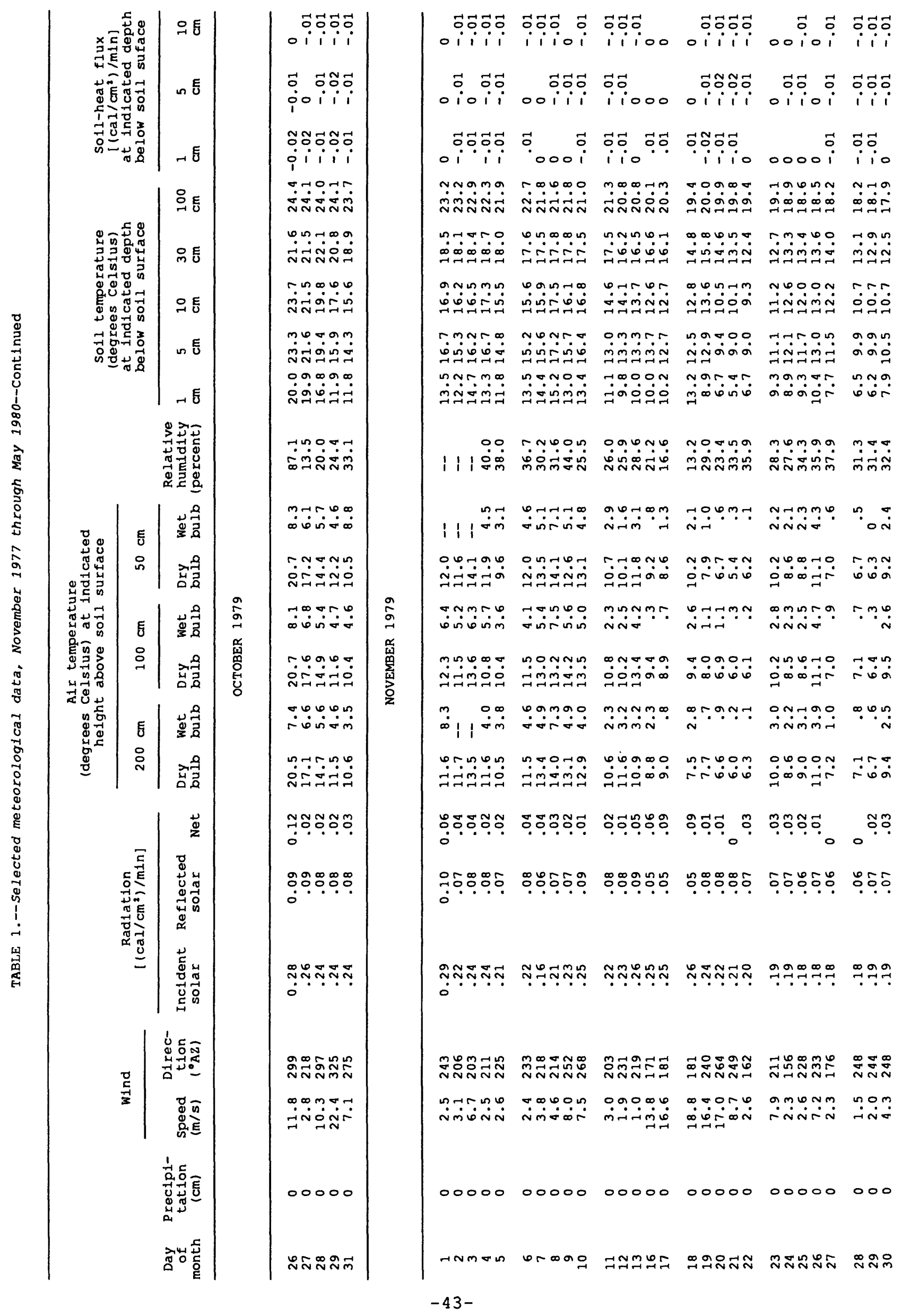




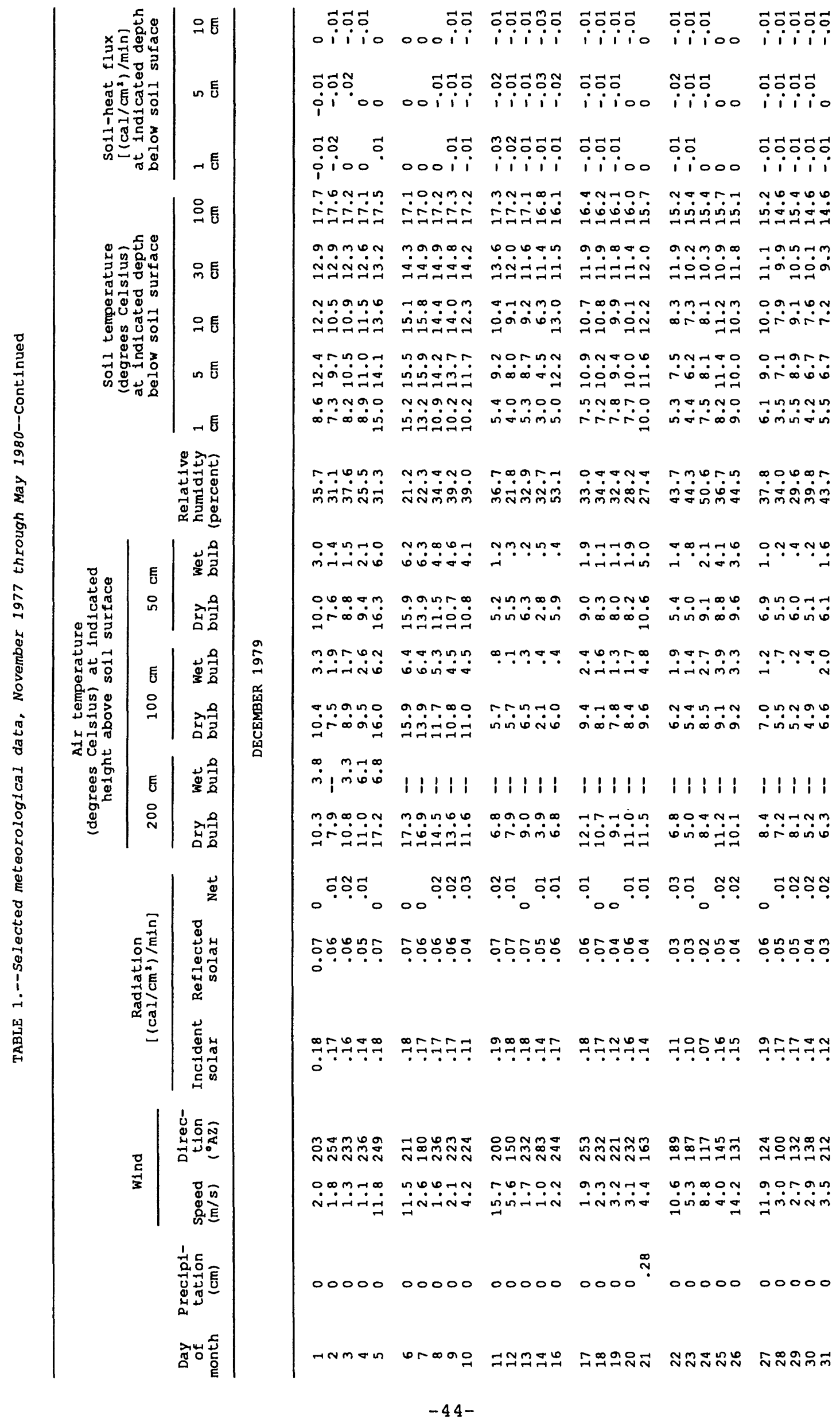




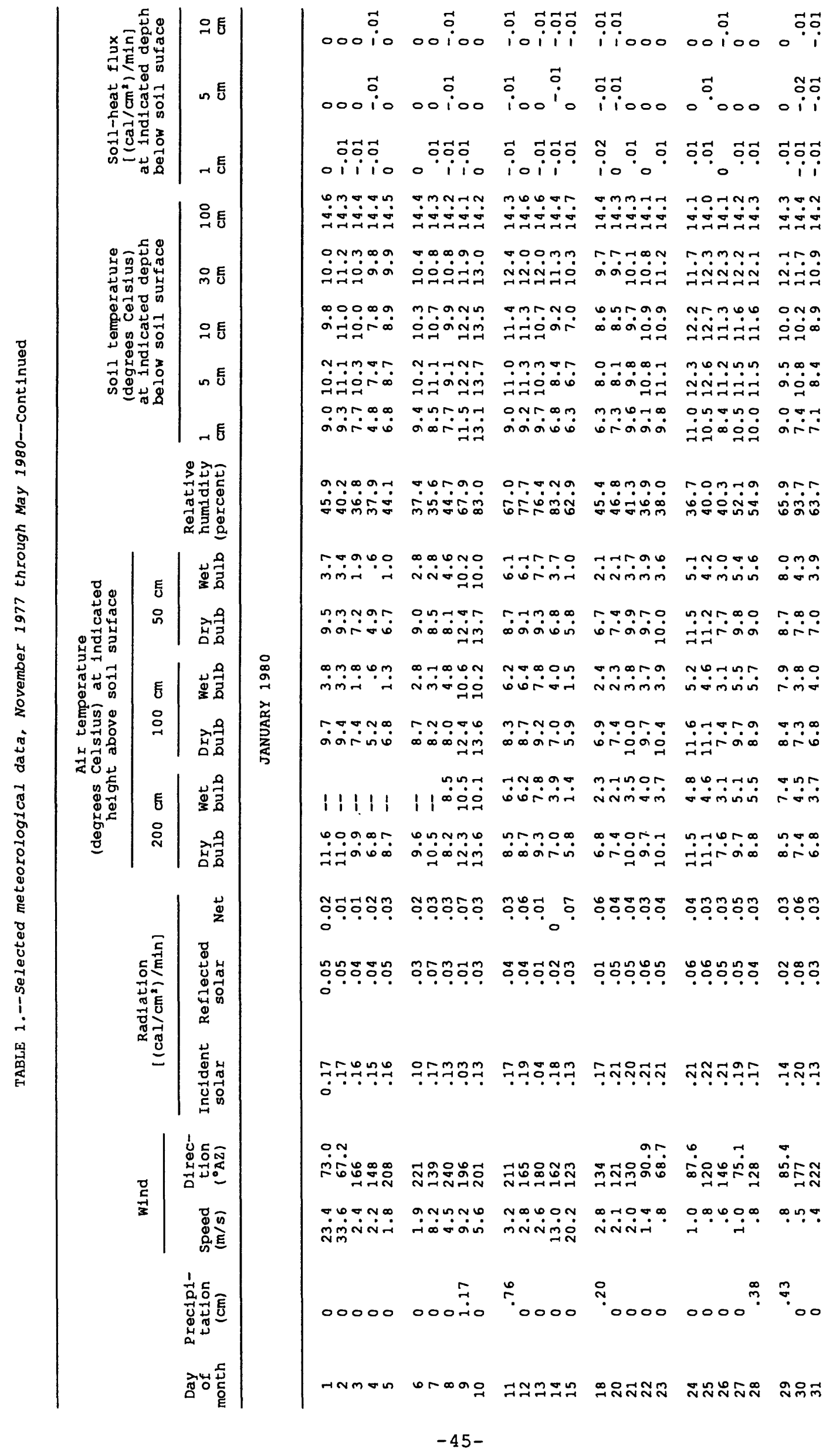




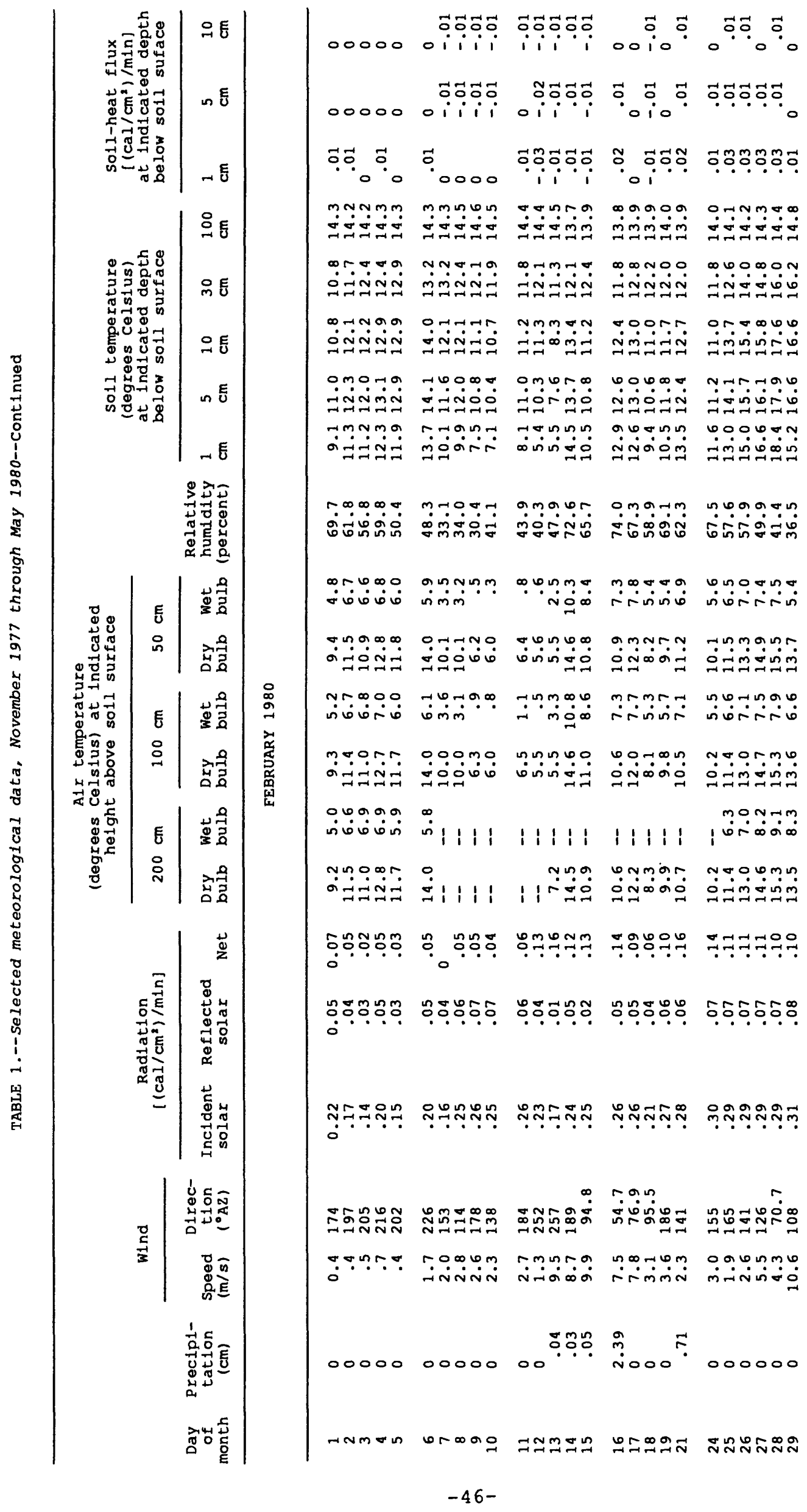




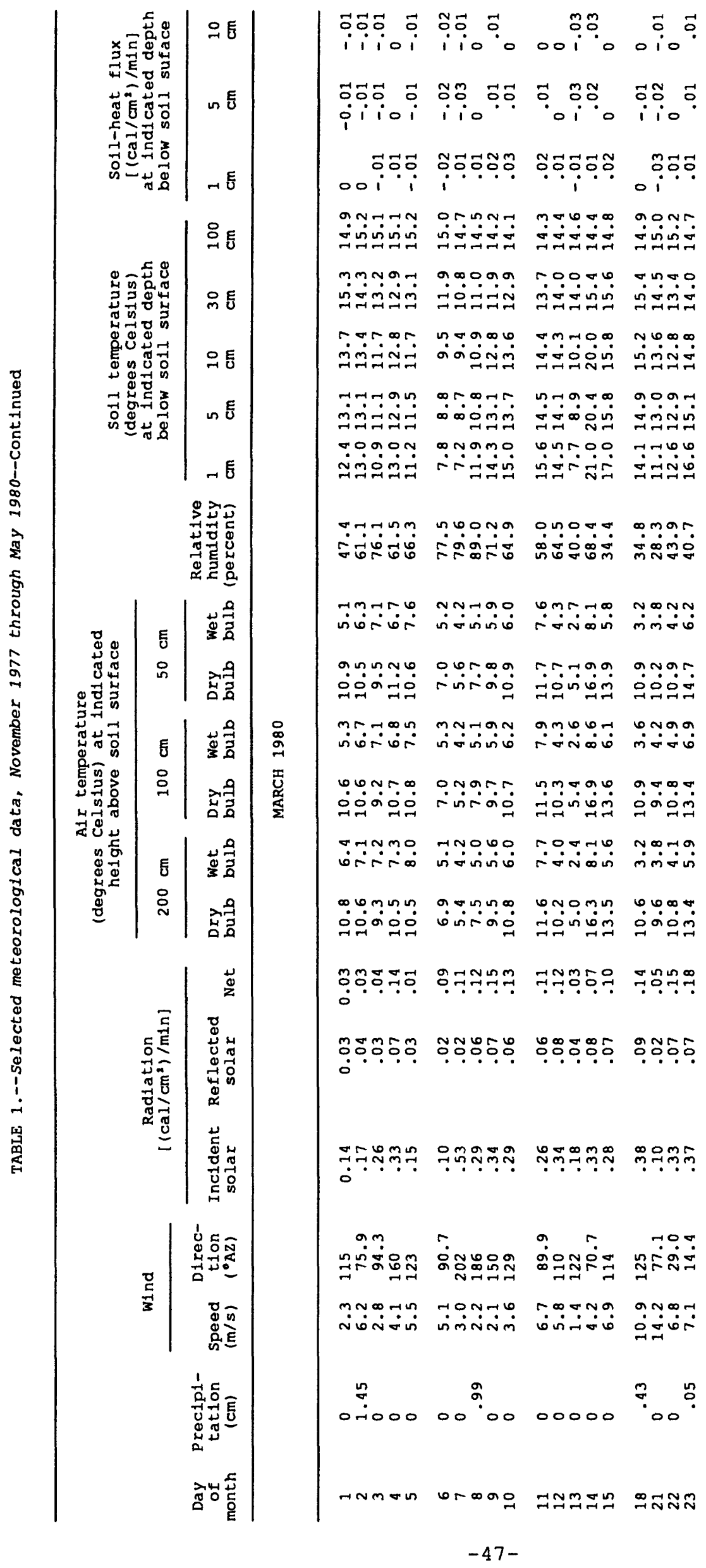




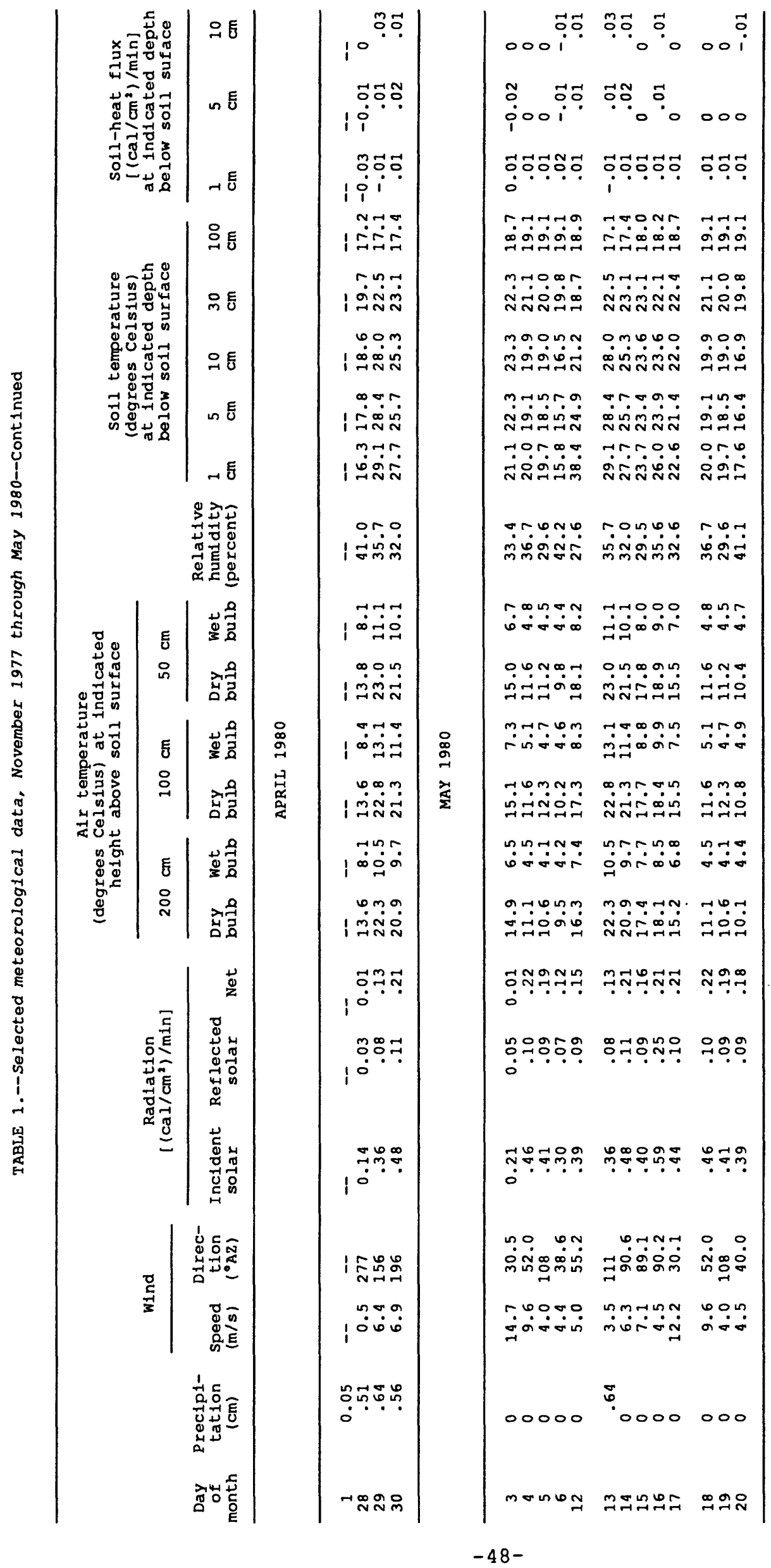

